\title{
Extrapolations on the Use of Rhizobium Inoculants Supplemented with Phosphorus (P) and Potassium (K) on Growth and Nutrition of Legumes
}

\author{
George W. Mmbaga, Kelvin M. Mtei, Patrick A. Ndakidemi* \\ School of Life Sciences and Bioengineering, the Nelson Mandela African Institution of Science and Technology, \\ Arusha, Tanzania \\ Email: mmbagag@nm-aist.ac.tz
}

Received 19 August 2014; revised 17 September 2014; accepted 24 October 2014

Copyright (C) 2014 by authors and Scientific Research Publishing Inc.

This work is licensed under the Creative Commons Attribution International License (CC BY). http://creativecommons.org/licenses/by/4.0/

\section{(c) (i) Open Access}

\begin{abstract}
Land scarcity and poor farming management practices has resulted in to intensive agriculture which rendered most of the soil in sub Saharan Africa depleted in essential plant nutrients. High prices of chemical fertilizer are crucial bottleneck toward increasing production of legumes and other food crops in most countries found in sub-Saharan Africa. Nitrogen, phosphorus and potassium are among the most limiting nutrients for plant growth as they play different but crucial roles in the plant physiological processes. These macronutrients are fundamental components of cell building blocks including genes and chromosomes. This review intend to show the vital roles played by rhizobial inoculants supplemented with phosphorus and potassium in enhancing growth, yield, photosynthesis, nodulation, nutrient uptake and nitrogen fixation of legumes.
\end{abstract}

\section{Keywords}

Biological Nitrogen Fixation (BNF), Nutrients, Legumes, Photosynthesis and Varieties

\section{Introduction}

Common bean (Phaseolus vulgaris L.) is an annual leguminous plant that belongs to the genus, Phaseolus, with pinnately compound trifoliate large leaves. Common bean shows variation in growth habits from determinate bush to indeterminate extreme climbing types [1]. Common bean is an important component of the production

${ }^{*}$ Corresponding author.

How to cite this paper: Mmbaga, G.W., Mtei, K.M. and Ndakidemi, P.A. (2014) Extrapolations on the Use of Rhizobium Inoculants Supplemented with Phosphorus (P) and Potassium (K) on Growth and Nutrition of Legumes. Agricultural Sciences, 5, 1207-1226. http://dx.doi.org/10.4236/as.2014.512130 
systems and a major source of protein for the poor in Eastern and southern Africa and the crop is grown mainly by women [1]-[3]. Generally, common bean (Phaseolus vulgaris L.) is considered a short-season crop with most varieties maturing in a range of 65 to 110 days from emergence to physiological maturity. Maturity period can continue up to 200 days after planting amongst climbers that are used in cooler upland elevations [4]. The climbing bean predominate the highland areas, where population density is high and land is limiting. Climbing bean production in the highlands of Eastern Africa is constraint by various factors ranging from biotic (diseases and pests) to abiotic ones such as soil nutrient availability commonly being limitation of $\mathrm{N}, \mathrm{P}$ and $\mathrm{K}$ [2] [5] [6].

Climbing bean is and is capable of producing a lot of biomass and grain yield in the limited space for planting, commonly grown in highlands where pressure on land is acute.

Climbing beans varieties are sub group of common beans growing vertically and are considered to be more advantageous over the bush type due to high grain yields of up to $5 \mathrm{t} / \mathrm{ha}$, diverse use as human and animal feeds, large biomass production and biological nitrogen fixation which is a basis for improvement of soil fertility [7] Furthermore, the indeterminate cultivars (climbing beans) play a key role in crop rotation and intercropping systems [8]. The climbing bean cultivars were developed with the purpose of adding more value in yield potentials and improve yield steadiness as compared with bush varieties [9]. Breeding of indeterminate beans was also aimed at combating the land scarce problem in highlands areas of sub Saharan Africa by which a small piece of land can be intensified and be utilized to its full capacity where by providing fully economic land value to the small holder farmers [10]. Thus, in this regards best plant architecture traits and the genes for disease resistance was also enhanced to climbing cultivars which renders them with the potential they hold [11] [12]. Indeterminate beans have been noted to give higher produce than determinate genotype in low plant populations which should therefore benefit subsistence small farmers who frequently plant low plant populations in order to lower seed costs [13] [14].

Dry bean production which is predominantly by small-scale farmers has been on the decline due to various constraints the major ones being diseases, low soil fertility and insect pests [15]. Small-scale farmers do not apply external inputs such as fertilizers, Rhizobium inoculants, fungicides and pesticides [16]. Due to these bottlenecks the production per hectare has declined from $800 \mathrm{~kg} \cdot \mathrm{ha}^{-1}$ in 1990 to less than $500 \mathrm{~kg} \cdot \mathrm{ha}^{-1}$ while the potential yield of climbing beans is estimated to be over $5000 \mathrm{~kg} \cdot \mathrm{ha}^{-1}$ under optimal water and nutrients supply and in the absence of other biotic factors such as pest and diseases [17] [18].

Nitrogen, phosphorus and potassium are chief elements that are richly available in the atmosphere (78\%) and soil (0.05\%) and (0.03) respectively, but in an inaccessible form to crop plants [19]. These elements are often limiting factors for plant growth and development [20]. Intensive farming practices that realize high yield and economic benefits to farmers do require some amount of industrial fertilizers as source of $\mathrm{P}$ and $\mathrm{K}$ plus rhizobia inoculants to supply nitrogen through process of BNF which is environmental friendly [21] [22].

Rhizobium inoculation increases the availability of nutrients to the plant and in the rhizosphere through process such as biological nitrogen fixation [23]. Being one of the major nutrients needed by the plant, nitrogen is an essential constituent of plant cells at structural, genetic and functional levels, involved in many processes of plant growth and development resulting to gain yield [24]. The extensive use of nitrogenous industrial fertilizers in agriculture is at present under debate due to environmental distress and doubts for consumer health. Consequently, there has recently been a growing level of interest in environmental friendly sustainable agricultural practices [25]. Increasing and extending the role of inoculation with microorganisms (bio-fertilizers) may decrease the need for industrial fertilizers and thereby reduce adverse environmental effects [26]. Thus; soil microorganisms are important living bodies in agriculture as they may play role of supporting the circulation of plant nutrients and thus trim down the need for industrial fertilizers [27].

Phosphorus is vital for development of new tissue and the transfer of the genetic information within the plant from one cell to another during cell formation [28]. It aids in energy transfer in form of ADP/ATP and thus being considered a very essential component in plant bioenergetics of the living cell [29].

Potassium (K) has an important role in regulating the water loss of plants thus help to prevent plant from necrosis [30]. It serves as an activator of enzymes used in photosynthesis and respiration, helps to build cellulose and aids in photosynthesis by the formation of a chlorophyll precursor and finally results in quality fruits [30] [31].

Many climbing beans varieties has been released and used by farmers in the highlands of East and sub Saharan Africa but there is lack of enough information about its agronomical and physiological performance in the field conditions when supplied with Rhizobium inoculants, Phosphorus (P) and Potassium (K) fertilizers. New 
varieties of climbing bean have been developed and released by various national programs. These have been introduced to farmer's fields in various African countries and are being grown in place of traditionally grown bush beans. However, there is little information on the response of the released climbing bean varieties with higher yielding potential when supplied with Rhizobium inoculation and supplementation with different levels of phosphorus and potassium in different agro ecological zones found in Africa. Thus, a need to cover this gap of knowledge by investigating the effect of Rhizobium inoculation and supplementation with different levels of phosphorus and potassium on growth, yield, $\mathrm{N}$-fixation, chlorophyll content, nutrients uptake and economic benefits of climbing beans varieties.

\section{Rhizobium Inoculation and Supplementation with $\mathrm{P}$ and $\mathrm{K}$ on Photosynthesis and Chlorophyll Contents of Climbing Beans Varieties (Phaseolus vulgaris L.)}

Nitrogen is a major constituent of chlorophyll, the most vital pigment needed for photosynthesis and amino acids synthesis [32] [33]. It is a factor in many biological compounds that plays a major role in photosynthetic activity and also acts as part of the enzymes associated with chlorophyll manufacturing which reflect relative crop nitrogen status present in leguminous plants. Nitrogen is a building block of proteins and is highly considered necessary for all enzymatic reactions in a plant [34]. Its supply has considerable effect on leaf growth because it increases the leaf area of plants and consequently it influences photosynthesis function of green plants [35] [36].

Generally, legumes and other leafy vegetables like cabbage, lettuce, amaranthus, Chinese cabbage and some fruit vegetables perform well when supplied with enough nitrogen as it improves the quality and quantity of dry matter and protein contents of the products [37]. However, green colour in the leaf tends to vanish when nitrogen become deficiency and this may cause the reduction in leaf vicinity and intensity of photosynthesis [38]. Nitrogen deficiency is normally associated with symptoms of yellowing, falling of leaves, reduced growth, late flowering and fruiting [37]. Nitrogen constitutes one of the major yield limiting factors for crop production, thus inoculation with appropriate strain of Rhizobium spp. can be an effective way of increasing growth and leaf chlorophyll content in legumes [39]-[41].

Inoculation of legumes with appropriate Rhizobium and supplementation with some nutrients especially phosphorus has been reported to increase the leaf chlorophyll content of legume crops [37] [41] [42]. For example, Bambara and Ndakidemi [6] reported Rhizobium inoculation of legumes to cause an increase in leaf chlorophyll content. Their findings in greenhouse indicated that leaf chlorophyll content significantly increased with rhizobial inoculation by $123 \%$ and $178 \%$ for the field experiment relative to control (without rhizobial inoculation treatment). Photosynthesis similarly increased significantly with rhizobial inoculation by $140 \%$ and $81 \%$ for the greenhouse and field experiment respectively, relative to un-inoculated control. Similarly, B. japonicum inoculation and phosphorus supplementation was reported to have significantly increased leaf chlorophyll content both in field and glasshouse experiment in soybean and cowpea [41] [42]. The increased chlorophyll content will result in the increased photosynthesis [43] and as a result plant gets enough sugars for its growth and production.

Green plants absorb sun light and convert its energy into usable biomass through the process of photosynthesis and produce diverse products of economic significance such as grain, fibre, tubers, fruits, vegetables, fodder and others [44]-[46]. This is accomplished by the plants provided that there is adequate light, appropriate temperature, and other support gears for plant metabolism such as water, carbon dioxide, oxygen, and a number of nutrients [44] [47].

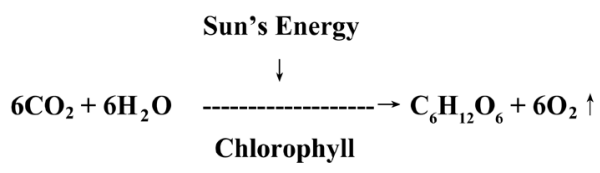

There are two types of chlorophyll in plants; viz chlorophyll $\boldsymbol{a}$ and $\boldsymbol{b}$, both works as photoreceptor in photosynthesis [48] [49]. While chlorophyll b helps in absorbing light and improves photosynthesis, it is reported to be more soluble in polar solvents due to its carboxyl group with a yellow colour and heavy ability to absorb blue light. The opposite is true for chlorophyll a. However, in shade adopted chloroplast, there is low ratio of chlorophyll a to chlorophyll $b$ [50]. Therefore, in legumes, increasing chlorophyll $b$ will increase the range of wavelengths absorbed by the shade chloroplasts and this will enhance photosynthesis for more growth and ultimately yield of legumes. 
Human operations such as application of agrochemicals have noticed to have a negative effect in chlorophyll contents of legumes [51]. As an important green pigment responsible to trap sun light, Chlorophyll enhances photosynthesis and creates glucose which refuels the plant metabolic processes and excess carbohydrates are being stored for future use by either plant itself or other organisms including human being [52]-[54]. Thus, supplementing legume plants with nutrients such as rhizobial for nitrogen fixation, phosphorus and potassium will improve the health of legumes and provide the necessary conditions for photosynthesis and ultimately increased yield [55].

Plants require phosphorus for growth throughout their life cycle, especially during the early stages of growth and development [56]. George [57] reported the major factor limiting plant growth and development to be the rate at which phosphorus regulates photosynthesis and carbohydrate metabolism in plant leaves. In photosynthesis and respiration, phosphorus has been reported to play a major role in energy storage and transfer as ADP and ATP (adenosine diphosphote and triphosphate) and DPN and TPN (diphosphopyridine and triphosphopyridine nucleotide) [58]. A deficiency of inorganic phosphate in the chloroplast was reported to reduce photosynthesis [59].

Potassium enhances photosynthesis and cell permeability and increases synthesis of amino acid into protein, it also facilitate cell division in young meristematic tissue, due to its effect on plant cell turgor and permeability, potassium indirectly assists in regulating the water economy of cells [60]. It is very important nutrient for cell organization, salt uptake and permeability into the xylem, the regulation of water uptake and transpiration, and in the metabolism of carbohydrates and nitrogen [61]. It also plays a key function in chlorophyll formation, the control of $\mathrm{pH}$ in the cells of the plant, and activates a number of enzymes [62]. Potassium is probably best known for its role in the opening of the stomata in the leaves and hence its role in regulating the rate of transpiration [63] [64]. Large quantities of potassium are normally found in the growing points of the plant, in the leaves and in the cell sap [65]. Furthermore common role of $\mathrm{K}$ in agronomy is closely connected with photosynthesis. Potassium enhances photosynthesis process at various levels, such as manufacturing of ATP, activation of the enzymes taking part in photosynthesis, $\mathrm{CO}_{2}$ uptake, and equilibrium of the electric charges needed for the process of photophosphorylation in chloroplasts, also acting as the counter ion to light-induced $\mathrm{H}^{+}$flux across the thylakoid membranes [57].

Legume crops such as peas, faba beans, and lentils need plenty of potassium during plant growth [66]. It is established that pulse crops regularly take twice as much $\mathrm{K}$ as compared with cereals crops. For example, $40 \mathrm{~kg}$ crop of peas requires about $110 \mathrm{~g}$ of $\mathrm{K}_{2} \mathrm{O}$, while a yield of $40 \mathrm{~kg}$ of faba beans needs over $200 \mathrm{~g}$. In contrast, 40 $\mathrm{kg}$ of spring wheat only takes up about $90 \mathrm{~g}$ of $\mathrm{K}_{2} \mathrm{O}$ [67]. Due to its essentiality in facilitating plant growth and its function in photosynthesis, potassium application in legumes based production field is inevitable.

There is very little information about effect of Rhizobium inoculants supplemented with $\mathrm{P}$ and $\mathrm{K}$ on photosynthesis and chlorophyll contents in legumes particularly the new climbing bean cultivars with huge potential in African highlands. Thus, there is need to explore the synergistic effects of supplying inoculants, $\mathrm{P}$ and $\mathrm{K}$ on enhancing the photosynthesis and chlorophyll contents of different climbing bean varieties recommend in Africa.

\section{Rhizobium Inoculants Supplemented with Nutrient Elements P and K on Nutrient Uptake in Legumes}

Nutrients are essential components required by living plants for normal growth and development. Among the needed 16 nutrients three (Carbon, hydrogen, and oxygen) are derived from the atmosphere and the rest are obtained from the soil, water, soil organic matter and inorganic fertilizers [68]. Shoot and root growth of virtually all legume crops is increased with balanced phosphorus and potassium nutrition [69]. Nutrient uptake by leguminous plants depends mainly in the quantity, concentration and activities in the root zone soil as well as the capacity of soil to replenish the concerned nutrients in the soil solution [70].

Nitrogen being one among the crucial nutrients required by plant for proper growth and development, has been reported to be the most limiting element due to the fact that it is prone to various losses including leaching, volatization and denitrification [71] [72]. Soil microorganisms such as Rhizobium and other plant growth promoting soil bacteria are known to have a constructive influence on the real chemistry of soils nutrients and thus promote nutrients uptake [73]-[75]. In recent decades, microbial inoculants have become promising components for integrated solution to environmental problems due to the fact that inoculants possess the capacity to promote plant growth, enhance nutrient availability and uptake and ultimately support the health of plant for better yield. 
Leguminous plants such as Phaseolus vulgaris and Vigna unguiculata (Walp) have the capacity of forming symbiotic relationship with Rhizobium bacteria which transform atmospheric $\mathrm{N}_{2}$ to soil nitrate or ammonium which can be utilized by leguminous plant for growth and development, in turn the leguminous plant provide housing and carbohydrates to the rhizobia [76]-[78]. Nyoki and Ndakidemi [79] disclosed that B. japonicum inoculants supplemented with phosphorus in cowpea improved the uptake of N, P, K, Mg, Ca and Na significantly relative to control. Makoi et al., [41] revealed that rhizobia inoculation significantly increased the uptake of P, K, $\mathrm{Ca}$, and $\mathrm{Mg}$ in plant parts such as leaves, shoots, roots and pods of common beans (Phaseolus vulgaris $\mathrm{L}$.).

Phosphorus is important in plant bioenergetics. As a component of ATP, phosphorus is needed for the conversion of light energy to chemical energy (ATP) during photosynthesis [80] [81]. Phosphorus can also be used to modify the activity of various enzymes by phosphorylation, and can be used for cell signaling [82]. It aids the plants in root development for smooth nutrients uptake [83], plant stalk and stem vitality, flower and seed creation, crop maturity and resistance to plant pests and diseases. For sustainable nutrient uptake and translocation into developing seeds during reproduction, root life span is important. P increases life span of legume roots and thus aid to provide plant carbon budget and favorable condition for nutrient uptake which finally have an impact in increasing seed yields [84] [85].

Phosphorus application in soil has been reported to influence the uptake and concentration of other nutrients in leaves and seeds [86]. Research shows that Phosphorus application had a positive and significant effect on the nutrients uptake such as Ca, Mg, Zn, Cu, Mn, and Fe [87] [88]. Tairo and Ndakidemi [89] reported that B. japonicum inoculants supplemented with phosphorus in cowpea (Vigna unguiculata (L.) Walp) significantly improved the uptake of a number of nutrients such as: N, P, K and Na in roots, pods, shoots and whole plant.

Furthermore the application of $\mathrm{P}$ and $\mathrm{K}$ fertilizers in combination with organic matter improved soil physical and chemical properties by enhancing biological activity and soil organic carbon accumulation thus helping in the uptake of nutrients [90]. Another study reported enhanced nitrate absorption and reduction to amino acids and increased the protein formation in plants following Rhizobium inoculation [91].

However, the uptake of nutrients in high yielding legume varieties supplied with Rhizobium and P and K supplements is not well established and hence need further investigation.

\section{Rhizobium Inoculants Supplemented with Nutrient Elements K and P on Growth of Climbing Bean Varieties (Phaseolus vulgaris L.)}

Rhizobium inoculation in legumes is ascribed to effect stimulation of growth and is therefore suggested to be the alternatives for the expensive inorganic industrial fertilizers [6] [92]. Nitrogen is provided through symbiotic fixation of atmospheric nitrogen by nitrogenase in rhizobial bacteroids [93]. As a macronutrient, nitrogen is required for cellular synthesis of enzymes, proteins, chlorophyll, amino acids, DNA and RNA, and is therefore important in plant growth [94]. Nitrogen is biologically combined with other building blocks such as $\mathrm{C}, \mathrm{H}, \mathrm{O}$ and $\mathrm{S}$, the combination of various amino acids form proteins. The amino acids are used in forming protoplasm, the site for cell division and thus for plant growth and development [95]. Nitrogen is the critical limiting element for growth of most plants due to its unavailability [96].

Climbing beans need nitrogen more than any other nutrient as nitrogen $(\mathrm{N})$ is a constituent of proteins, enzymes, chlorophyll, and growth regulators [97]. Deficiency of nitrogen causes diminutive growth, leaf yellowing, abridged branching and tiny trifoliate leaves in legumes [98] [99]. Plants attain nitrogen from two main sources: the soil, through industrial fertilizer, manure, and/or decomposition and mineralization of organic matter; and the atmosphere through symbiotic nitrogen fixation [100] [101]. However, small-scale subsistence farmers who are the principal dry bean producers infrequently apply commercial fertilizers in bean production field; hence the crop is basically dependent on fixed nitrogen [102].

Leguminous crops including climbing beans, posses root nodules, fix and utilize atmospheric nitrogen [103] [104]. They are thus not mostly dependent on industrially fixed nitrogen and may add up to $30 \mathrm{~kg}$ of nitrogen per hectare to the soil and improve its fertility [105] [106]. Being a leguminous crop, climbing beans (Phaseolus vulgaris L.) has unique properties of symbiotically associating with Rhizobium leguminosarum and convert atmospheric nitrogen into a usable form to the plants and some may be leaked to the soil and therefore influencing other biological process in the soil [68]. Evidence from the research findings by Rodelas et al. [107], suggests that Rhizobium inoculation of legumes and the subsequent nitrogen fixation process could have positive effect on plant growth and finally the macro and micronutrients availability and thus improving the nutritional quality 
of different plant components [68] [87] [89].

Biological Nitrogen Fixation infrequently covers the full nitrogen requirement of beans [108]. Many researchers have reported the importance of $\mathrm{N}$ in beans yields and research evidence revealed that common bean responded very well to nitrogenous fertilization of up to $200 \mathrm{~kg} \cdot \mathrm{ha}^{-1}$ [109]-[113]. However, other researchers have shown that they have the ability to use about $50 \%$ of its $\mathrm{N}$ requirement from the atmospheric $\mathrm{N}_{2}$ fixation [114] [115]. However, this is in contrast to soybeans and other legumes which are in need of little or no nitrogen as a starter fertilizer to establish efficient symbiosis with nitrogen fixing bacteria and afterward cover most of their nitrogen demand through BNF [104] [116].

Climbing beans undergo symbiotic interaction with rhizobia capable of fixing atmospheric nitrogen $\left(\mathrm{N}_{2}\right)$. This consists of formation of nodules on host roots, which harbour the bacterial symbionts, and the $\mathrm{N}_{2}$ fixation process in the nodules, which occurs thereafter [117]. In recent years, a number of Rhizobium inoculants have been developed and are primarily used for supplying nitrogen to plants by enhancing $\mathrm{N}_{2}$ fixation [79]. Symbiotic nitrogen fixation in soybeans can provide from $65 \mathrm{~kg}$ to more than $160 \mathrm{~kg}$ fixed nitrogen ha ${ }^{-1}$ [118] [119] representing about $40 \%-70 \%$ of soybeans nitrogen requirements.

Ravikumar et al.; [117] in their study on artificial inoculation of Rhizobium japonicum on the production of two pulse grains (Vigina mungo and Vigina radiate), reported that there was a statistically significance percentage increase in all parameters studied over the non inoculated counterpart. In their results for both varieties studied, the inoculated plants obsessed significant increases in growth and yield potential over the respective non inoculated control plants (greater height, greater fresh weight, greater number of roots, nodules, greater number of leaves, shoots, pods, greater length of pods and greater seed weight). Thus inoculation of seed beans with appropriate Rhizobium strains for superior nitrogen fixation provides an alternative to the application of commercial nitrogenous fertilizers [120] [121]. Other researchers have also reported the increase in legume plant height, number of leaves, and leaf area index and plant girth due to Rhizobium inoculation [37] [42] [122].

Unlike Nitrogen, Phosphorus is the element which is frequently found to be most limiting nutrient for plant physiological activities such as growth and maturity in the production soils of the tropics [69]. It is among the critical macro-nutrient needed by plant for its well-being. However, about $40 \%-50 \%$ of African legumes production areas are affected by moderate to severe phosphorus deficiency [115] [123]. Phosphorus has a major role in carbon, hydrogen, oxygen and fat metabolism, and plays an important role in respiration and photosynthesis [124]. Deficiency symptoms of P include signs of dwarfed plants with thin malformed stems and shortened internodes; small, dark-green upper leaves, and few numbers of pods formed which contains only a tiny number of seeds [115] [125]. Low soil phosphorus status is categorized as a constraint of high significance in 70\% (957,000 ha) of legumes production area in Eastern Africa [123].

This nutrient is vital to plant growth and is found in every living plant cell [86] [126]. It plays significant key roles in plant functions, such as energy transfer as ADP/ATP, photosynthesis, transformation of sugars and starches, nutrient movement within the plant and phosphorylation [127] [128]. ATP is very important in the process of nitrogen fixation as it is required to break the triple bond that exists between $\mathrm{N}$ atoms in $\mathrm{N}_{2}$-molecules.

Though, many tropical soils are phosphorus deficient due to various reasons, the element is required by legumes in trace quantities [129]. Despite of being critical nutrient to yields of climbing beans due to its multiple effects on nutrition, all growing plants require phosphorus for growth and development [108] [130]. The low amount of native available phosphorus in Sub Saharan Africa soils is thought to be associated with total soil phosphorus contents of the parent soil forming materials or due to high P-fixing capacity favored by their high Aluminum (Al) and Iron (Fe) oxide contents and their low pH status [131] [132].

Graham [105], Thung and Rao [133] reported significance of P in growth and yield of Phaseolus vulgaris, their findings showed that there was about $60 \%-70 \%$ yield reduction in beans associated with growth retardation of both below and above ground plant organs that resulted from $\mathrm{P}$ deficiency. As mentioned earlier, $\mathrm{P}$ helps in enhancing Biological Nitrogen Fixation in legumes [96] [121] [134], the reason being high P demand of Biological nitrogen fixation process which creates additional sink of phosphorus to the plant in the nodule thus, deprives the legume plant of the $P$ acquired from the soil [135] [136].

Several workers [1] [37] [69] [102] [133] [137]-[139] have suggested exogenous application of appropriate phosphorus fertilizer as a means of correcting low phosphorus soils, like those frequently encountered in sub Saharan Africa so as to ensure positive effect on growth, Biological nitrogen fixation and yields of targeted legumes. For example, Tairo and Ndakidemi [37] reported phosphorus to have significantly increased plant height, 
number of leaves, leaf chlorophyll content, stem girth, leaf area (LA) and leaf area index (LAI) on soybean when inoculated with $B$. japonicum both in the screen house and field experiments. Increased plant height with increased phosphorus application was also reported by [138] [139]. This could be due to the fact that phosphorus being essential constituent of plant tissue significantly influences the plant height of legume crops [69] [137] [139]. Phosphorus (P) deficiency is widespread in most regions where both (Climbing/Bush type) and other legumes are produced in Africa, It is possibly the constraint that mostly hinders nitrogen fixation [2].

Potassium amount found in plant tissue including leguminous plants is close to that of nitrogen thus making potassium the second element needed by plant in large quantity [140] [141]. It increases the efficiency of the leaf in manufacturing sugars and starch, and its action is considered to be complementary to that of nitrogen [142]. While nitrogen increases the size of the leaf, potassium increases its photosynthesis efficiency and thus contributes to the growth of the plant [143] [144].

Rhizobium inoculants, phosphorus and potassium when supplied together have shown a positive outcome on growth and yield of many leguminous plants grown both in the screen house and field [145]-[150]. Therefore, this signifies the importance of using these nutrients in combination in a given plant ecosystem where common bean farming is practiced. Furthermore, the information on the synergetic effect of the package on the growth of newly released bean varieties in African landscape is very limited.

\section{Expected Effects of Rhizobium Inoculation and Supplementation with P and K on Nodulation and Nitrogen Fixation on Legumes}

Nitrogen fixation involving symbiotic association between Rhizobium and leguminous plant such as $P$. vulgaris in which the Rhizobium bacteria do convert the nitrogen from the air in to the soil and transform it to ammonium $\left(\mathrm{NH}_{4}\right)$, which can be direct taken and be used by host plant [103] [104] [151]. The presence of appropriate rhizobial strains in the soil is of paramount importance for $\mathrm{N}_{2}$ fixation to take place. Studies conducted in East African Highlands by [21] showed that the population of common beans and other selected legume nodule forming Rhizobium ranged from zero to very small number [21]. Under such conditions it is necessary to inoculate legumes with rhizobial inoculants [152]. Generally, it is established that under optimum conditions $\mathrm{N}_{2}$ fixation in legumes is reported to fulfill between $50 \%-60 \%$ of legume nitrogen requirements [153].

Most grain legumes are capable of fixing atmospheric $\mathrm{N}_{2}$ through the association with rhizobia [114]. The legume plant supplies sugar for bacterial growth while the bacteria fix atmospheric $\mathrm{N}_{2}$ into $\mathrm{NH}_{4}^{+}$or $\mathrm{NO}_{3}^{-}$, to be converted into both essential and non essential amino acids that can be used by the plant to synthesize proteins for its growth and development [154] [155]. The simplified equation for nitrogen fixation is shown in Figure 1 below.

The process of Biological nitrogen fixation (BNF) shown in Figure 1 is accomplished by specific strain of nodule forming bacteria for the specific type of legumes, for example Rhizobium leguminosarum bv viciae induces nitrogen fixing nodules on Pisum, Vicia, Lens, and Lathyrus spp., while R. leguminosarum bv trifolii do initiates nodules only on species of clover (Trifolium) and Sinorhizobium meliloti effectively nodulates species of Medicago, Melilotus, and Trigonella [156] [157]. If the Rhizobium strains mentioned above are not adequately present in the growth media, or the inefficient strain capable of initiating the nitrogen fixing process dominates, then nodulation and $\mathrm{N}_{2}$ fixation will be constrained [74] [158]-[160]. The solution to the aforementioned constraints is through seed or soil inoculation with the proper Rhizobium bacteria before or at planting [109] [161]-[163].

Several researchers have reported the effects of Rhizobium inoculation on nodulation and nitrogen fixation on legumes [164]-[166]. Subba et al. [167] performed study on the comparative efficiency of Rhizobium japoni-

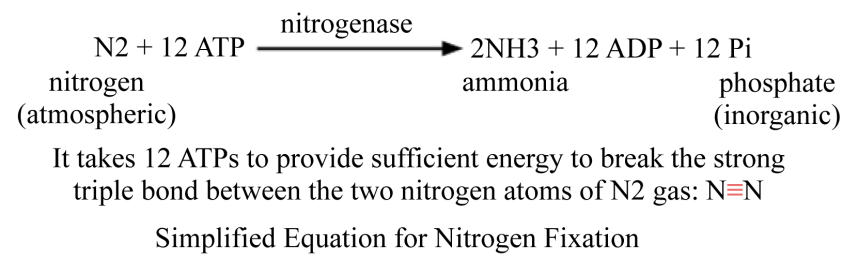

Figure 1. Simplified equation for nitrogen fixation (Source: waynesword.palomar.edu). 
cum on soybeans grown in the field, the study findings showed that inoculation with UPAU-culture resulted in significant nodulation. They also reported improved nodulation in Cajanus cajan, Cicer arietinum and Lens culinaris when neutral soils was inoculated with Rhizobium inoculants.

Phosphorus, like potassium, is essential for nitrogen fixation in legumes. Several studies have shown that $\mathrm{N}_{2}$ fixation is reduced when phosphorus is deficient [168]-[170]. With adequate phosphorus, $\mathbf{N}_{2}$ fixation is improved through increased nitrogen-use efficiency [2] [59] [171]. Phosphorus does not only increases seed yields but also nodulation [172] postulated $P$ concentration in seed to be a source of early nodulation on legumes especially in soils with low phosphorus contents and thus enhances early establishment of symbiosis. Furthermore, phosphorus has stimulating effect on plant nodule development and action of nitrogenase enzyme in nodules of leguminous plants [173]-[176]. Phosphorus application is also reported to significantly enhance number of nodules; nodules dry weight, nitrogen and phosphorus uptake of the cowpea [177]. On the opposite, its deficiency decreased nodule mass [178]-[181] nodule quantity [174] [178] and function of nitrogenase enzyme [175] [182][184].

Potassium plays a critical role in enzyme activation, water use efficiency, photosynthesis, transport of sugars, protein synthesis, and starch synthesis in plants [185] [186] is especially important in its interaction with nitrogen throughout the growth cycle. Adequate potassium in the field results in higher crop yields and higher nitrogen-use efficiency as it enhance nodulation and hence $\mathrm{N}_{2}$ fixation, [181]. Crops respond to higher potassium levels when nitrogen is sufficient, and greater yield response to nitrogen occurs when potassium is sufficient [187], thus a complementary uptake for the plant growth and development. Therefore, contribution of $\mathrm{N}$ fixation in $\mathrm{K}$ nutrition of legumes is very important.

Abbasi et al. [164], Abdelhamid et al. [188], Parthipan and Kulasooriya [189] reported that the addition of K in legumes increase dry matter yield of nodule, nodule number, nodule fresh weight per plant and nodule average weight. Also total nitrogen accumulation in the legume plant and enzyme nitrogenase activity increased with increasing K supply. Potassium increases metabolism of nitrogen in legumes plants. For example, Mengel et al., [190] reported high accumulation of ${ }^{15} \mathrm{~N}$ isotope in the soluble amino fraction and in the protein fraction of various leguminous plant organs especially root nodule as a ressult of high $\mathrm{K}$ supply contrary to plants supplied with small amount of potassium. Furthermore, K supply on legumes such as Vicia faba resulted into greater sugar supply to the nodules and a higher sugar yield in the nodules thus improving the provision of ATP and decreasing negative charges needed by the nitrogenase enzyme and lastly improved $\mathrm{N}_{2}$ fixation.

Sangakkara et al. [191] reported that, elevated potassium supply had affirmative effect on nitrogen fixation and has a positive effect on shoot and root growth. $\mathrm{K}$ amendment improved the nodule activity of legumes, the number of nodules formed, fresh weight of nodules, and amount of $\mathrm{N}_{2}$ - fixed per nodule [191] [192].

The combined influence Rhizobium inoculation and supplementation with phosphorus and potassium on symbiotic nitrogen fixation and nodulation in new released leguminous varieties from the breeding programs in Africa has received little attention. So, it is important to study the possible combined role that could be played by $\mathrm{P}, \mathrm{K}$ and Rhizobium inoculants on symbiotic nitrogen fixation in new released leguminous varieties growing in diverse environment such as those found in East African Highlands.

\section{Anticipated Effect of Rhizobium Inoculation, Phosphorus (P) and Potassium (K) Supply on Yield of Grain Legumes}

Limiting factors such as diversity or scarcity of native Rhizobium population in soil can affect the legume performance and grain yield [179] [193]-[195]. Supplementing climbing legumes with nutrients has great potential for increasing yield as it is not only promoting growth but also enhance symbiotic establishment for increased nitrogen fixation [153] [196] [197]. In situation where field legumes are exogenously supplied with mineral nutrients they tend to double plant growth, nitrogen fixation and grain yield relatively to their unfertilized counterparts [148] [198].

Nitrogen is a very important macro-nutrient largely involved in metabolic actions and protein synthesis, resulting to increased vegetative and reproductive growth and ultimately leads to yield of the crops [199] [200]. Being the most limiting nutrients to plant physiological process, nitrogen supply to plants has been commonly accomplished by application of industrial fertilizer in various places in Africa [57]. This common solution of nitrogen amendment is extremely expensive and unsustainable to small holder farmers and it is environmental unfriendly [201]-[203].

According to the following researchers [21] [23] [42] solution to nitrogen bottleneck in East and sub Saharan 
Africa for the purpose of enhancing legume productivity in the region is through Rhizobium inoculation. This will maximize the inherent trait of legume plant species which are capable of solely obtain $\mathrm{N}$ required for growth and development from Biological Nitrogen Fixation [204].

Various researchers have performed studies on the effects of Rhizobium inoculants on legumes grown in the field and screen house and reported to have positive results in yield increase. For example, Bambara and Ndakidemi [6]; Nyoki and Ndakidemi [79] reported that Rhizobium inoculation significantly improved the yield and yield components of legumes such as number of pods per plant, number of seeds per pod, number of seeds per plant, 100-seed weight, and seed yield relative to control. The increase in seed yield could be due to high nodulation which results in high $\mathrm{N}_{2}$ fixation and hence higher stover yield and seed yield.

Research findings suggests that intensification of rhizobial population through inoculation amplified grain yields by $22.5 \%$ in treatments with phosphorus fertilizer (TSP) and by $6.8 \%$ in non-TSP fertilized plots, demonstrating that Rhizobium augmentation had a positive effect above the naturally occurring Rhizobium strains [205]. Moreover Giller [42]; Nyoki and Ndakidemi [78], investigation revealed that the plants which were inoculated with rhizobial inoculants gave significantly higher stover yield and seed yield compared with un-inoculated control, the reason could be high nodulation which result in high nitrogen fixation and consequently higher stover and seed yield [206].

P deficiency is also a chief contributing factor limiting BNF in legumes [105] [133]. Phosphorus is required in large quantities in juvenile cells, such as shoots tips and root tips, where metabolism is high and cell division is quick [59]. Phosphorus aids in root expansion, flower commencement, and seed and fruit development [207]. Yield of beans can be reduced by as much as $60 \%-75 \%$ in soils that are unable to release sufficient $\mathrm{P}$ levels during the growing season.

Studies have shown that phosphorus availability in soils was found to have a positive influence in survival and efficiency of Rhizobium bacteria which are responsible for fixing atmospheric nitrogen in legumes. Thus it helps in boosting roots proliferation, shoot growth, flower initiation, seeds and fruits expansion and ultimately total yield of legumes [208]. Many researchers have reported a significant performance of legumes when supplied with phosphorus [102] [209]-[211]. In the study conducted by Turuko and Mohammed [212] in Ambo University, Ethiopia to investigate effect of different fertilizer rate on growth, dry matter yield and yield components of common bean, it was revealed that phosphorus significantly increased dry matter yield, yield components and growth parameters such as leaf area and number of branches per plant and finally the seed yield.

$\mathrm{K}^{+}$is highly mobile and can aid in balancing the anion charges within the plant. Potassium regulates the opening and closing of the plant stomata, thus helping to prevent water loss through transpiration and hence affecting growth and yield [131]. Research findings indicates that potassium application in corn and soyabean increased average yields of both crop when applied at the rate of $120 \mathrm{~kg} \cdot \mathrm{K} \cdot \mathrm{ha}^{-1}$ based on soil potassium test recommendations as compared with lower rates. The importance of potassium on increasing yields was also revealed in other crops rather than legumes. For example, Borges and Mallarino [213]; Turuko and Mohammed [212] reported K removal in tubers ranged from 203 to $397 \mathrm{~kg} / \mathrm{ha}$ and was direct proportional to tuber yield, that is, the more the plant absorbs $\mathrm{K}^{+}$the more the yield it produce. Like nitrogen, the importance of potassium in legume production has to be considered and taken into action for proper yield.

The very low nitrogen, phosphorus and potassium status of many soils in East African highlands suggests that availability of these elements will be an emerging limitation to crop productivity in the near future. Therefore, Rhizobium inoculation, potassium and phosphorus supply may play a crucial role in enhancing legume productivity in poorly depleted soils of East Africa. Therefore, the synergetic effect of inoculation and nutrient supplementation (K and $\mathrm{P}$ ) in single or in combination and their influence on the yield of new released legume varieties such as those involving $P$. vulgaris needs to be investigated.

\section{Promising Economic Benefits of Rhizobium Inoculants and Supplementation with P and $\mathrm{K}$ in Production of Climbing Beans Varieties (Phaseolus vulgaris)}

Various types of pulses are important source of income to farmers in African region, and the efforts at improving their yield has increasing over the year [110]. Despite the attractive market of pulses, the yield of grain legumes has remained very low under farmer's condition in Africa. Studies revealed that the low yields of legumes in Africa is sought to be associated with low soil fertility, low native Rhizobium and thus reduced $\mathrm{N}_{2}$ fixation as a results of various abiotic factors such as N and P [204] [214]. Most farmers in highlands of East Afri- 
ca are aware of the aforesaid soil constraint thus, N. P. K fertilizers are applied in major food security crops such as Zea mays and Oryza sativa [215] and very little is used in legumes.

Nitrogen deficiency problem in legumes may be ameliorated by rhizobial inoculants through seed dressing at planting. Several workers have stipulated that Rhizobium inoculation in legumes can fix atmospheric nitrogen between 15 and $210 \mathrm{~kg} \cdot \mathrm{N} \cdot \mathrm{ha}^{-1}$ [41] [216] [217]. The maximum amount fixed $\mathrm{N}$ is approximately equivalent to nine bags of UREA $(46 \% \mathrm{~N})$, the cost of one bag of urea is estimated at T.shs. $65,000 /=(40$. US\$) thus a total input cost of T.shs. 585,000/= (355. US\$) for fertilizing one hactre with the equivalent nitrogen which can be covered by 100g Rhizobium inoculant (Bio fix) sold at only T.shs, 1600/= (1.US\$) Therefore the use of rhizobial inoculants is less expensive than industrial fertilizer for small scale agriculture which is practiced in most sub-Saharan Africa and cover majority of the people of which, chemical fertilizers are unaffordable because of increasing prices in each year. Thus, to these farmers Biological Nitrogen Fixation which is enhanced by inoculation to the compatible host legume is recommended as it is considered to have ecological and high economic benefits.

Studies by Ndakidemi et al. [37]; Nyoki and Ndakidemi [79]; Tairo and Ndakidemi [102] worked out economic analysis of rhizobial inoculation and phosphorus supplementation on cowpea, soybean and common beans grown under field conditions in Kilimanjaro region in Tanzania. These studies revealed greater financial benefits from rhizobial inoculation compared with un-inoculated control. For example, inoculation on cowpea have resulted into greater income of 495.2 US\$ as profit relative to uninoculated treatments which offered a profit of 307.4 US\$ and ultimately resulted into higher percentage increase over control and marginal rate of return. However phosphorus supplementation at the rate of (40 kg.P/ha) gave greater revenue as profit over all other treatments [42].

According to Ndakidemi et al. [37] on yield and economic payback of legume inoculation under farmer conditions, in Rombo and Moshi districts-Kilimanjro Tanzania, Rhizobial inoculation technology was proved to be capable of giving good results like industrial nitrogenous fertilizer. In this study biofertilizer applied in soybean and common bean produced bumper harvest on field conditions. Relative to control treatments, the economic analysis performed on common beans revealed 66\% and 92\% profit margin increase in Moshi and Rombo districts respectively. Furthermore when inoculation was supplemented with P at the rate of $26 \mathrm{~kg} / \mathrm{ha}$ the recorded profit margin increased to $84 \%$ and $102 \%$ respectively. However with soybeans the reported figure was $140 \%$ and $153 \%$ for Rombo and Moshi district respectively when rhizobial alone was used and with P supplementation at the same rate as above the profit margin increased up to $224 \%$ and $250 \%$ for Rombo and Moshi respectively.

Thus, inoculation of newly release legume varieties such as climbing beans recommended for growth in African highlands is essential for obtaining profitable and sustainable yield. Furthermore, inoculation with effective Rhizobium strains and supplementation with phosphorus and potassium will supply enough nitrogen, phosphorus and potassium to the legumes and hence enhancing grain yield and finally resulting into higher economic benefits to the growers.

\section{Conclusion}

Rhizobium inoculation based Agriculture for new released legume varieties such as those involving climbing bean production are of paramount importance especially for resource limited farmers in areas where land is scarce and productivity is low due to nutrients depletion. Thus, rhizobial inoculation and supplementation with phosphorus and potassium has constructive effect in improving photosynthesis, nutrient uptake, nodulation, growth, yield and economic benefits in legumes. Thus the use of Rhizobium inoculation for the resource poor farmers to enhance biological nitrogen fixation and supplementation with optimum amounts of phosphorus and potassium for small and large scale production of legumes is strongly recommended in Africa.

\section{Acknowledgements}

This study was funded by Tanzania Commission for Science and Technology (COSTECH) and The Nelson Mandela African Institution of Science and Technology (NM-AIST).

\section{References}

[1] Katungi, E., Farrow, A., Chianu, J., Sperling, L. and Beebe, S. (2009) Common Bean in Eastern and Southern Africa: 
A Situation and Outlook Analysis. International Centre for Tropical Agriculture, $61 \mathrm{p}$.

[2] Ndakidemi, P.A. (2006) Manipulating Legume/Cereal Mixtures to Optimize the Above and Below Ground Interactions in the Traditional African Cropping Systems. African Journal of Biotechnology, 5.

[3] David, S., Kirkby, R. and Kasozi, S. (2000) Assessing the Impact of Bush Bean Varieties on Poverty Reduction in Sub-Saharan Africa: Evidence from Uganda: CIAT. Network on Bean Research in Africa.

[4] Buruchara, R. (2007) Background Information on Common Beans (Phaseolus vulgaris L.) in Biotechnology, Breeding \& Seed Systems for African Crops. The Rockefeller Foundation, Nairobi.

[5] Avis, T.J., Gravel, V., Antoun, H. and Tweddell, R.J. (2008) Multifaceted Beneficial Effects of Rhizosphere Microorganisms on Plant Health and Productivity. Soil Biology and Biochemistry, 40, 1733-1740. http://dx.doi.org/10.1016/j.soilbio.2008.02.013

[6] Bambara, S. and Ndakidemi, P.A. (2010) The Potential Roles of Lime and Molybdenum on the Growth, Nitrogen Fixation and Assimilation of Metabolites in Nodulated Legume: A Special Reference to Phaseolus vulgaris L. African Journal of Biotechnology, 9, 2482-2489.

[7] Gicharu, G., Gitonga, N., Boga, H., Cheruiyot, R. and Maingi, J. (2013) Effect of Inoculating Selected Climbing Bean Cultivars with Different Rhizobia Strains on Nitrogen Fixation.

[8] Lambrecht, I., Maertens, M., Vranken, L., Merckx, R. and Vanlauwe, B. (2013) Heterogeneous Preferences for Integrated Soil Fertility Management: A Choice Experiment on Climbing Beans in Burundi. Bioeconomics Working Paper Series, Working Paper 2013/32013.

[9] Nienhuis, J. and Singh, S. (1988) Genetics of Seed Yield and its Components in Common Bean (Phaseolus vulgaris L.) of Middle-American Origin. Plant Breeding, 101, 143-154. http://dx.doi.org/10.1111/j.1439-0523.1988.tb00280.x

[10] Jaradat, A.A. (2010) Genetic Resources of Energy Crops: Biological Systems to Combat Climate Change. Australian Journal of Crop Science, 4, 309.

[11] Blair, M.W., Fregene, M.A., Beebe, S.E. and Ceballos, H. (2007) Marker-Assisted Selection in Common Beans and Cassava. In: Guimarães, E., Ruane, J., Scherf, B., Sonnino, A. and Dargie, J., Eds., Marker-Assisted Selection: Current Status and Future Perspectives in Crops, Livestock, Forestry and Fish, Food and Agriculture Organization of the United Nations, Rome, 81-115.

[12] Boukar, O. and Fatokun, C. (2009) Strategies in Cowpea Breeding. In: Tadele, Z., Ed., New Approaches to Plant Breeding of Orphan Crops in Africa, Organizing Committee of the International Conference on New Approaches to Plant Breeding of Orphan Crops in Africa, Bern, 69-92.

[13] Kelly, J., Adams, M. and Varner, G. (1987) Yield Stability of Determinate and Indeterminate Dry Bean Cultivars. Theoretical and Applied Genetics, 74, 516-521. http://dx.doi.org/10.1007/BF00289831

[14] Schneider, K.A., Brothers, M.E. and Kelly, J.D. (1997) Marker-Assisted Selection to Improve Drought Resistance in Common Bean. Crop Science, 37, 51-60. http://dx.doi.org/10.2135/cropsci1997.0011183X003700010008x

[15] Kimenju, J., Karanja, N. and Macharia, I. (1999) Plant Parasitic Nematodes Associated with Common Bean in Kenya and the Effect of Meloidogyne Infection on Bean Nodulation. African Crop Science Journal, 7, 503-510. http://dx.doi.org/10.4314/acsj.v7i4.27744

[16] Galhardi, R.M.A. (1995) Biotechnology for Poverty Alleviation in Third World Countries. Technology and Developing Countries: Practical Applications, Theoretical Issues, 12, 94.

[17] Elliott, L. and Lynch, J. (1995) The International Workshop on Establishment of Microbial Inocula in Soils: Cooperative Research Project on Biological Resource Management of the Organization for Economic Cooperation and Development (OECD). American Journal of Alternative Agriculture, 10, 50-73. http://dx.doi.org/10.1017/S0889189300006160

[18] Verdoodt, A. and Van Ranst, E. (2006) Environmental Assessment Tools for Multi-Scale Land Resources Information Systems: A Case Study of Rwanda. Agriculture, Ecosystems \& Environment, 114, 170-184. http://dx.doi.org/10.1016/j.agee.2005.10.006

[19] Acharya, S., Bera, S., Gupta, K., Basumatary, S., Bera, S. and Ahmed, M. (2012) Bamboo Cultivation in Garo Hills of Meghalaya, North East India: A Potential Agroforestry System to Protect Environment. Biological Sciences and Engineering, 3, 195.

[20] Russell, E.J. (2002) Soil Conditions and Plants Growth. Daya Books (Longmans, Green \& Co.).

[21] Sanchez, P.A., Shepherd, K.D., Soule, M.J., Place, F.M., Buresh, R.J., I Izac, A.-M., et al. (1997) Soils Fertility Replenishment in Africa: An Investment in Natural Resource Capital. Replenishing Soil Fertility in Africa, 51, 1-46.

[22] Gruhn, P., Goletti, F. and Yudelman, M. (2000) Integrated Nutrient Management, Soil Fertility and Sustainable Agriculture: Current Issues and Future Challenges. International Food Policy Research Institute, Washington DC. 
[23] Bambara, S. and Ndakidemi, P.A. (2010) Changes in Selected Soil Chemical Properties in the Rhizosphere of Phaseolus vulgaris L. Supplied with Rhizobium Inoculants, Molybdenum and Lime. Scientific Research and Essays, 5, 679684.

[24] Graham, P. and Ranalli, P. (1997) Common Bean (Phaseolus vulgaris L.). Field Crops Research, 53, 131-146. http://dx.doi.org/10.1016/S0378-4290(97)00112-3

[25] Lowe, P. and Baldock, D. (2000) Integration of Environmental 3 Objectives into Agricultural Policy. CAP Regimes and the European Countryside: Prospects for Integration between Agricultural, Regional, and Environmental Policies, 31.

[26] Integration Between Agricultural, Regional, and Environmental Policies, 31.Mia, M.B. and Shamsuddin, Z. (2013) Rhizobium as a Crop Enhancer and Biofertilizer for Increased Cereal Production. African Journal of Biotechnology, 9, 6001-6009.

[27] Biswas, T.D. and Mukherjee, S. (2001) Textbook of Soil Sciences. Tata McGraw-Hill Education, Noida.

[28] Rausch, C., Daram, P., Brunner, S., Jansa, J., Laloi, M., Leggewie, G., et al. (2001) A Phosphate Transporter Expressed in Arbuscule-Containing Cells in Potato. Nature, 414, 462-470. http://dx.doi.org/10.1038/35106601

[29] Hüttemann, M., Lee, I., Samavati, L., Yu, H. and Doan, J.W. (2007) Regulation of Mitochondrial Oxidative Phosphorylation through Cell Signaling. Biochimica et Biophysica Acta (BBA)-Molecular Cell Research, 1773, 1701-1720.

[30] Broun, P.E., Creelman, R.A., DuBell, A.N., Heard, J.E., Jiang, C.-Z., Keddie, J., et al. (2006) Biochemistry-Related Polynucleotides and Polypeptides in Plants. United States Patent No. 7135616.

[31] Pretorius, H. (2009) The Ability of a Novel Compound to Enhance the Effect of Urea on Nitrogen Deficient Tomatoes. University of the Free State, Bloemfontein.

[32] Hörtensteiner, S. and Feller, U. (2002) Nitrogen Metabolism and Remobilization during Senescence. Journal of Experimental Botany, 53, 927-937. http://dx.doi.org/10.1093/jexbot/53.370.927

[33] Maathuis, F.J. (2009) Physiological Functions of Mineral Macronutrients. Current Opinion in Plant Biology, 12, 250258. http://dx.doi.org/10.1016/j.pbi.2009.04.003

[34] Hokmalipour, S. and Darbandi, M.H. (2011) Effects of Nitrogen Fertilizer on Chlorophyll Content and Other Leaf Indicate in Three Cultivars of Maize (Zea mays L.). World Applied Sciences Journal, 15, 1780-1785.

[35] Evans, J.R. (1989) Photosynthesis and Nitrogen Relationships in Leaves of C3 Plants. Oecologia, 78, 9-19. http://dx.doi.org/10.1007/BF00377192

[36] Lloyd, J. and Farquhar, G. (1996) The $\mathrm{CO}_{2}$ Dependence of Photosynthesis, Plant Growth Responses to Elevated Atmospheric $\mathrm{CO}_{2}$ Concentrations and Their Interaction with Soil Nutrient Status. I. General Principles and Forest Ecosystems. Functional Ecology, 10, 4-32. http://dx.doi.org/10.2307/2390258

[37] Tairo, E.V. and Ndakidemi, P.A. (2013) Bradyrhizobium japonicum Inoculation and Phosphorus Supplementation on Growth and Chlorophyll Accumulation in Soybean (Glycine max L.). American Journal of Plant Sciences, 4, 22812289. http://dx.doi.org/10.4236/ajps.2013.412282

[38] De Ron, A.M., Cubero, J.I., Singh, S.P. and Aguilar, O.M. (2013) Cultivated Legume Species. International Journal of Agronomy, 2013, Article ID: 324619.

[39] Rondon, M.A., Lehmann, J., Ramírez, J. and Hurtado, M. (2007) Biological Nitrogen Fixation by Common Beans (Phaseolus vulgaris L.) Increases with Bio-Char Additions. Biology and Fertility of Soils, 43, 699-708. http://dx.doi.org/10.1007/s00374-006-0152-z

[40] Rajendran, G., Sing, F., Desai, A.J. and Archana, G. (2008) Enhanced Growth and Nodulation of Pigeon Pea by Co-Inoculation of Bacillus Strains with Rhizobium spp. Bioresource Technology, 99, 4544-4550. http://dx.doi.org/10.1016/j.biortech.2007.06.057

[41] Makoi, J.H., Bambara, S. and Ndakidemi, P.A. (2013) Rhizobium Inoculation and the Supply of Molybdenum and Lime Affect the Uptake of Macroelements in Common Bean (P. vulgaris L.) Plants. Australian Journal of Crop Science, 7, 784-793.

[42] Nyoki, D. and Ndakidemi, P.A. (2014) Effects of Phosphorus and Bradyrhizobium japonicum on Growth and Chlorophyll Content of Cowpea (Vigna unguiculata (L.) Walp). American Journal of Experimental Agriculture, 4, 1120-1136. http://dx.doi.org/10.9734/AJEA/2014/6736

[43] Sylvie, B. and Patrick, A.N. (2009) Effects of Rhizobium Inoculation, Lime and Molybdenum on Photosynthesis and Chlorophyll Content of Phaseolus vulgaris L. African Journal of Microbiology Research, 3, 791-798.

[44] Roy, R., Finck, A., Blair, G. and Tandon, H. (2006) Plant Nutrition for Food Security: A Guide for Integrated Nutrient Management (FAO Fertilizer and Plant Nutrition Bulletins). Food and Agriculture Organization of the United Nations, Rome 
[45] Barber, J. (2009) Photosynthetic Energy Conversion: Natural and Artificial. Chemical Society Reviews, 38, $185-196$. http://dx.doi.org/10.1039/b802262n

[46] Ahluwalia, V. (2013) Environmental Studies: Basic Concepts. TERI Press, New Delhi.

[47] Hofmann, E.E., Cahill, B., Fennel, K., Friedrichs, M.A., Hyde, K., Lee, C., et al. (2011) Modeling the Dynamics of Continental Shelf Carbon. Annual Review of Marine Science, 3, 93-122. http://dx.doi.org/10.1146/annurev-marine-120709-142740

[48] Bennett, J. (1981) Biosynthesis of the Light-Harvesting Chlorophyll a/b Protein. European Journal of Biochemistry, 118, 61-70. http://dx.doi.org/10.1111/j.1432-1033.1981.tb05486.x

[49] Bennett, J. (1983) Regulation of Photosynthesis by Reversible Phosphorylation of the Light-Harvesting Chlorophyll a/b Protein. Biochemical Journal, 212, 1-13.

[50] Kitajima, K. and Hogan, K. (2003) Increases of Chlorophyll a/b Ratios during Acclimation of Tropical Woody Seedlings to Nitrogen Limitation and High Light. Plant, Cell \& Environment, 26, 857-865. http://dx.doi.org/10.1046/j.1365-3040.2003.01017.x

[51] Birch, A.N.E., Begg, G.S. and Squire, G.R. (2011) How Agro-Ecological Research Helps to Address Food Security Issues under New IPM and Pesticide Reduction Policies for Global Crop Production Systems. Journal of Experimental Botany, 62, 3251-3261. http://dx.doi.org/10.1093/jxb/err064

[52] Marchand, P.J. (2000) Autumn: A Season of Change. UPNE, Lebanon.

[53] Simmons, A. (2009) Encyclopedia of Adaptations in the Natural World. ABC-CLIO, Santa Barbara.

[54] Zobiole, L., Oliveira Jr., R., Kremer, R., Constantin, J., Yamada, T., Castro, C., et al. (2010) Effect of Glyphosate on Symbiotic $\mathrm{N}_{2}$ Fixation and Nickel Concentration in Glyphosate-Resistant Soybeans. Applied Soil Ecology, 44, 176-180. http://dx.doi.org/10.1016/j.apsoil.2009.12.003

[55] Dimkpa, C., Weinand, T. and Asch, F. (2009) Plant-Rhizobacteria Interactions Alleviate Abiotic Stress Conditions. Plant, Cell \& Environment, 32, 1682-1694. http://dx.doi.org/10.1111/j.1365-3040.2009.02028.x

[56] Römer, W. and Schilling, G. (1986) Phosphorus Requirements of the Wheat Plant in Various Stages of Its Life Cycle. Plant and Soil, 91, 221-229. http://dx.doi.org/10.1007/BF02181789

[57] George, E., Marschner, H. and Jakobsen, I. (1995) Role of Arbuscular Mycorrhizal Fungi in Uptake of Phosphorus and Nitrogen from Soil. Critical Reviews in Biotechnology, 15, 257-270. http://dx.doi.org/10.3109/07388559509147412

[58] Black Jr., C.C. (1973) Photosynthetic Carbon Fixation in Relation to Net $\mathrm{CO}_{2}$ Uptake. Annual Review of Plant Physiology, 24, 253-286. http://dx.doi.org/10.1146/annurev.pp.24.060173.001345

[59] Uchida, R. (2000) Essential Nutrients for Plant Growth: Nutrient Functions and Deficiency Symptoms. In: Silva, J.A. and Uchida, R., Eds., Plant Nutrient Management in Hawaii's Soils, Approaches for Tropical and Subtropical Agriculture, College of Tropical Agriculture and Human Resources, University of Hawaii at Manoa, Honolulu, 31-55.

[60] Rojo, M., Carcedo, S.G. and Mateos, M. (1990) Distribution and Characterization of Phosphatase and Organic Phosphorus in Soil Fractions. Soil Biology and Biochemistry, 22, 169-174. http://dx.doi.org/10.1016/0038-0717(90)90082-B

[61] Amtmann, A., Hammond, J.P., Armengaud, P. and White, P.J. (2005) Nutrient Sensing and Signalling in Plants: Potassium and Phosphorus. Advances in Botanical Research, 43, 209-257. http://dx.doi.org/10.1016/S0065-2296(05)43005-0

[62] Van Bel, A.J. (1990) Xylem-Phloem Exchange via the Rays: The Undervalued Route of Transport. Journal of Experimental Botany, 41, 631-644. http://dx.doi.org/10.1093/jxb/41.6.631

[63] Waraich, E.A., Ahmad, R., Ashraf, M.Y., Saifullah and Ahmad, M. (2011) Improving Agricultural Water Use Efficiency by Nutrient Management in Crop Plants. Acta Agriculturae Scandinavica, Section B-Soil \& Plant Science, 61, 291-304.

[64] Chrispeels, M.J., Morillon, R., Maurel, C., Gerbeau, P., Kjellbom, P. and Johansson, I. (2001) Aquaporins of Plants: Structure, Function, Regulation and Role in Plant Water Relations. Current Topics in Membranes, 51, 277-334. http://dx.doi.org/10.1016/S1063-5823(01)51009-1

[65] Leigh, R. and Wyn Jones, R. (1984) A Hypothesis Relating Critical Potassium Concentrations for Growth to the Distribution and Functions of This Ion in the Plant Cell. New Phytologist, 97, 1-13. http://dx.doi.org/10.1111/j.1469-8137.1984.tb04103.x

[66] Hamdi, Y.A. (1982) Application of Nitrogen-Fixing Systems in Soil Improvement and Management. Food \& Agriculture Organization, Rome.

[67] Graham, R.D., Welch, R.M., Saunders, D.A., Ortiz-Monasterio, I., Bouis, H.E., Bonierbale, M., et al. (2007) Nutritious Subsistence Food Systems. Advances in Agronomy, 92, 1-74. http://dx.doi.org/10.1016/S0065-2113(04)92001-9

[68] Ndakidemi, P.A., Bambara, S. and Makoi, J.H. (2011) Micronutrient Uptake in Common Bean (Phaseolus vulgaris L.) 
as Affected by Rhizobium Inoculation and the Supply of Molybdenum and Lime. Plant Omics Journal, 4, 40-52.

[69] Fageria, N.K., Baligar, V.C. and Jones, C.A. (2011) Growth and Mineral Nutrition of Field Crops. CRC Press, Boca Raton.

[70] Killham, K. (1994) Soil Ecology. Cambridge University Press, Cambridge.

[71] Rotz, C. (2004) Management to Reduce Nitrogen Losses in Animal Production. Journal of Animal Science, 82, E119E137.

[72] Stark, C.H. and Richards, K.G. (2008) The Continuing Challenge of Agricultural Nitrogen Loss to the Environment in the Context of Global Change and Advancing Research. Dynamic Soil, Dynamic Plant, 2, 1-12.

[73] Dobbelaere, S., Vanderleyden, J. and Okon, Y. (2003) Plant Growth-Promoting Effects of Diazotrophs in the Rhizosphere. Critical Reviews in Plant Sciences, 22, 107-149. http://dx.doi.org/10.1080/713610853

[74] Bais, H.P., Weir, T.L., Perry, L.G., Gilroy, S. and Vivanco, J.M. (2006) The Role of Root Exudates in Rhizosphere Interactions with Plants and Other Organisms. Annual Review of Plant Biology, 57, 233-266. http://dx.doi.org/10.1146/annurev.arplant.57.032905.105159

[75] Lugtenberg, B. and Kamilova, F. (2009) Plant-Growth-Promoting Rhizobacteria. Annual Review of Microbiology, 63, 541-556. http://dx.doi.org/10.1146/annurev.micro.62.081307.162918

[76] Gaur, Y. (1993) Microbiology, Physiology and Agronomy of Nitrogen Fixation: Legume-Rhizobium Symbiosis. Proceedings of the Indian National Science Academy Part B, 59, 333-333.

[77] Glick, B.R. (1995) The Enhancement of Plant Growth by Free-Living Bacteria. Canadian Journal of Microbiology, 41, 109-117. http://dx.doi.org/10.1139/m95-015

[78] Giller, K.E. (2001) Nitrogen Fixation in Tropical Cropping Systems. Cabi.

[79] Nyoki, D. and Ndakidemi, P.A. (2014) Effects of Bradyrhizobium japonicum Inoculation and Supplementation with Phosphorus on Macronutrients Uptake in Cowpea (Vigna unguiculata (L.) Walp). American Journal of Plant Sciences, 5, 442-451. http://dx.doi.org/10.4236/ajps.2014.54058

[80] Allen, M.B., Whatley, F. and Arnon, D.I. (1958) Photosynthesis by Isolated Chloroplasts: VI. Rates of Conversion of Light into Chemical Energy in Photosynthetic Phosphorylation. Biochimica et Biophysica Acta, 27, 16-23. http://dx.doi.org/10.1016/0006-3002(58)90288-9

[81] Allen, J.F. (2002) Photosynthesis of ATP_Electrons, Proton Pumps, Rotors and Poise. Cell, 110, 273-276. http://dx.doi.org/10.1016/S0092-8674(02)00870-X

[82] Connolly, T.M., Lawing Jr., W.J. and Majerus, P.W. (1986) Protein Kinase C Phosphorylates Human Platelet Inositol Trisphosphate 5'-Phosphomonoesterase, Increasing the Phosphatase Activity. Cell, 46, 951-958. http://dx.doi.org/10.1016/0092-8674(86)90077-2

[83] Rengel, Z. (2012) 2. Nutrient Management in Organic Farming and Consequences for Direct and Indirect Selection Strategies. Organic Crop Breeding, Published Online.

[84] Fisher, M.C., Eissenstat, D.M. and Lynch, J.P. (2002) Lack of Evidence for Programmed Root Senescence in Common Bean (Phaseolus vulgaris) Grown at Different Levels of Phosphorus Supply. New Phytologist, 153, 63-71. http://dx.doi.org/10.1046/j.0028-646X.2001.00285.x

[85] Wittwer, S.H. (1995) Food, Climate and Carbon Dioxide: The Global Environment and World Food Production. CRC Press, Boca Raton.

[86] Schachtman, D.P., Reid, R.J. and Ayling, S.M. (1998) Phosphorus Uptake by Plants: From Soil to Cell. Plant Physiology, 116, 447-453. http://dx.doi.org/10.1104/pp.116.2.447

[87] Nyoki, D. and Ndakidemi, P.A. (2014) Influence of Bradyrhizobium japonicum and Phosphorus on Micronutrient Uptake in Cowpea. A Case Study of Zinc (Zn), Iron (Fe), Copper (Cu) and Manganese (Mn). American Journal of Plant Sciences, 5, 427-435. http://dx.doi.org/10.4236/ajps.2014.54056

[88] Fageria, N., Zimmermann, F. and Baligar, V. (1995) Lime and Phosphorus Interactions on Growth and Nutrient Uptake by Upland Rice, Wheat, Common Bean and Corn in an Oxisol. Journal of Plant Nutrition, 18, 2519-2532. http://dx.doi.org/10.1080/01904169509365081

[89] Tairo, E.V. and Ndakidemi, P.A. (2014) Macronutrients Uptake in Soybean as Affected by Bradyrhizobium japonicum Inoculation and Phosphorus (P) Supplements. American Journal of Plant Sciences, 5, 488-496. http://dx.doi.org/10.4236/ajps.2014.54063

[90] Anetor, M. and Akinrinde, E. (2006) Response of Soybean [Glycine max (L.) Merrill] to Lime and Phosphorus Fertilizer Treatments on an Acidic Alfisol of Nigeria. Pakistan Journal of Nutrition, 5, 286-293. http://dx.doi.org/10.3923/pjn.2006.286.293

[91] Hagin, J., Olsen, S. and Shaviv, A. (1990) Review of Interaction of Ammonium-Nitrate and Potassium Nutrition of 
Crops. Journal of Plant Nutrition, 13, 1211-1226. http://dx.doi.org/10.1080/01904169009364147

[92] Chianu, J.N., Nkonya, E.M., Mairura, F., Chianu, J.N. and Akinnifesi, F. (2010) Biological Nitrogen Fixation and Socioeconomic Factors for Legume Production in Sub-Saharan Africa: A Review. Agronomy for Sustainable Development, 31, 139-154.

[93] Mylona, P., Pawlowski, K. and Bisseling, T. (1995) Symbiotic Nitrogen Fixation. The Plant Cell, 7, 869-885. http://dx.doi.org/10.1105/tpc.7.7.869

[94] Amtmann, A. and Armengaud, P. (2009) Effects of N, P, K and S on Metabolism: New Knowledge Gained from Multi-Level Analysis. Current Opinion in Plant Biology, 12, 275-283. http://dx.doi.org/10.1016/j.pbi.2009.04.014

[95] Lewis, O.A. (1991) Plants and Nitrogen. Cambridge University Press, Cambridge.

[96] Vance, C.P. (2001) Symbiotic Nitrogen Fixation and Phosphorus Acquisition. Plant Nutrition in a World of Declining Renewable Resources. Plant Physiology, 127, 390-397. http://dx.doi.org/10.1104/pp.010331

[97] Reich, P. and Schoettle, A. (1988) Role of Phosphorus and Nitrogen in Photosynthetic and Whole Plant Carbon Gain and Nutrient Use Efficiency in Eastern White Pine. Oecologia, 77, 25-33. http://dx.doi.org/10.1007/BF00380920

[98] Stevens, G., Motavalli, P.P., Scharf, P.C., Nathan, M. and Dunn, D.D. (2002) Crop Nutrient Deficiencies and Toxicities. MU Extension, University of Missouri-Columbia, Columbia.

[99] Fageria, N. and Baligar, V. (2005) Enhancing Nitrogen Use Efficiency in Crop Plants. Advances in Agronomy, 88, 97185. http://dx.doi.org/10.1016/S0065-2113(05)88004-6

[100] Crews, T. and Peoples, M. (2004) Legume versus Fertilizer Sources of Nitrogen: Ecological Tradeoffs and Human Needs. Agriculture, Ecosystems \& Environment, 102, 279-297. http://dx.doi.org/10.1016/j.agee.2003.09.018

[101] Hofman, G., Van Cleemput, O. and Association, I.F.I. (2004) Soil and Plant Nitrogen. International Fertilizer Industry Association, Paris.

[102] Ndakidemi, P., Dakora, F., Nkonya, E., Ringo, D. and Mansoor, H. (2006) Yield and Economic Benefits of Common Bean (Phaseolus vulgaris) and Soybean (Glycine max) Inoculation in Northern Tanzania. Animal Production Science, 46, 571-577. http://dx.doi.org/10.1071/EA03157

[103] Phillips, D.A. (1980) Efficiency of Symbiotic Nitrogen Fixation in Legumes. Annual Review of Plant Physiology, 31, 29-49. http://dx.doi.org/10.1146/annurev.pp.31.060180.000333

[104] Neves, M.C.P., Hungria, M. and Sprent, J. (1987) The Physiology of Nitrogen Fixation in Tropical Grain Legumes. Critical Reviews in Plant Sciences, 6, 267-321. http://dx.doi.org/10.1080/07352688709382252

[105] Graham, P. (1984) Plant Factors Affecting Nodulation and Symbiotic Nitrogen Fixation in Legumes. In: Alexander, M., Ed., Biological Nitrogen Fixation, Springer US, New York, 75-98.

[106] Ramaekers, L. (2011) Climbing for Nitrogen: Genetic Analysis of Symbiotic Nitrogen Fixation Capacity and Adoption Analysis in Climbing Beans. KU Leuven, Leuven.

[107] Rodelas, B., González-López, J., Martinez-Toledo, M., Pozo, C. and Salmeron, V. (1999) Influence of Rhizobium/Azotobacter and Rhizobium/Azospirillum Combined Inoculation on Mineral Composition of Faba Bean (Vicia faba L.). Biology and Fertility of Soils, 29, 165-169. http://dx.doi.org/10.1007/s003740050540

[108] Rao, I.M., Friesen, D., Osaki, M. and Pessarakli, M. (1999) Plant Adaptation to Phosphorus-Limited Tropical Soils. In: Pessarakli, M., Ed., Handbook of Plant and Crop Stress, 2nd Edition, CRC Press, Boca Raton, 61-96.

[109] Graham, P. and Vance, C. (2000) Nitrogen Fixation in Perspective: An Overview of Research and Extension Needs. Field Crops Research, 65, 93-106.

[110] Giller, K., Amijee, F., Brodrick, S. and Edje, O. (1998) Environmental Constraints to Nodulation and Nitrogen Fixation of Phaseolus vulgaris L. in Tanzania II. Response to N and P Fertilizers and Inoculation with Rhizobium. African Crop Science Journal, 6, 171-178. http://dx.doi.org/10.4314/acsj.v6i2.27813

[111] Wortmann, C. (1988) Review of Bean Responses to Applied Fertilizers in Africa. Proceedings of a Workshop on Soil Fertility Research for Bean Cropping Systems in Africa, Addis Ababa, 5-9 September 1988, 111.

[112] Mayona, C. and Kamasho, J. (1988) Research Experiences with Inorganic and Organic Fertilizers in the Southern Highlands of Tanzania. International Center for Tropical Agriculture, Cali.

[113] Daba, S. and Haile, M. (2002) Effects of Rhizobial Inoculant and Nitrogen Fertilizer on Yield and Nodulation of Common Bean under Intercropped Conditions. Journal of Plant Nutrition, 25, 1443-1455. http://dx.doi.org/10.1081/PLN-120005401

[114] Pereira, P., Burris, R. and Bliss, F. (1989) 15N-Determined Dinitrogen Fixation Potential of Genetically Diverse Bean Lines (Phaseolus vulgaris L.). Plant and Soil, 120, 171-179. http://dx.doi.org/10.1007/BF02377066

[115] Wortmann, C.S., Lunze, L., Ochwoh, V.A. and Lynch, J. (1995) Bean Improvement for Low Fertility Soils in Africa. African Crop Science Journal, 3, 469-477. 
[116] Kuklinsky-Sobral, J., Araújo, W.L., Mendes, R., Geraldi, I.O., Pizzirani-Kleiner, A.A. and Azevedo, J.L. (2004) Isolation and Characterization of Soybean-Associated Bacteria and Their Potential for Plant Growth Promotion. Environmental Microbiology, 6, 1244-1251. http://dx.doi.org/10.1111/j.1462-2920.2004.00658.x

[117] Ravikumar, R. (2012) Growth Effects of Rhizobium Inoculation in Some Legume Plants. International Journal of Current Science, 2012, 1-6.

[118] Catroux, G. and Amarger, N. (1992) Rhizobia as Soil Inoculants in Agriculture. In: Fry, J.C., Day, M. and Lynch, J., Eds., Release of Genetically Engineered and Other Micro-Organisms, Cambridge University Press, Cambridge, 1-13.

[119] Zablotowicz, R.M. and Reddy, K.N. (2007) Nitrogenase Activity, Nitrogen Content and Yield Responses to Glyphosate in Glyphosate-Resistant Soybean. Crop Protection, 26, 370-376. http://dx.doi.org/10.1016/j.cropro.2005.05.013

[120] Dommergues, Y.R. (1987) The Role of Biological Nitrogen Fixation in Agroforestry. In: Steppler, H.A. and Nair, P.K.R., Eds., Agroforestry: A Decade of Development, ICRAF, Nairobi, 245-271.

[121] Shantharam, S. and Mattoo, A.K. (1997) Enhancing Biological Nitrogen Fixation: An Appraisal of Current and Alternative Technologies for N Input into Plants. In: Ladha, J.K., de Bruijn, F.J. and Malik, K.A., Eds., Opportunities for Biological Nitrogen Fixation in Rice and Other Non-Legumes, Springer, Dordrecht, 205-216.

[122] Bambara, S. and Ndakidemi, P.A. (2010) Phaseolus vulgaris Response to Rhizobium Inoculation, Lime and Molybdenum in Selected Low pH Soil in Western Cape, South Africa. African Journal of Agricultural Research, 5, $1804-1811$.

[123] Wortmann, C.S. (1998) Atlas of Common Bean (Phaseolus vulgaris L.) Production in Africa. CIAT, Cali.

[124] Soetan, K., Olaiya, C. and Oyewole, O. (2010) The Importance of Mineral Elements for Humans, Domestic Animals and Plants: A Review. African Journal of Food Science, 4, 200-222.

[125] Salad, C. (2007) Diseases of Vegetable Crops. In: Koike, S.T., Gladders, P. and Paulus, A.O., Eds., Vegetable Diseases: A Color Handbook, Academic Press, Burlington, 420.

[126] Gerdemann, J. (1968) Vesicular-Arbuscular Mycorrhiza and Plant Growth. Annual Review of Phytopathology, 6, 397418. http://dx.doi.org/10.1146/annurev.py.06.090168.002145

[127] Rao, I. and Pessarakli, M. (1996) The Role of Phosphorus in Photosynthesis. In: Pessarakli, M., Ed., Handbook of Photosynthesis, Marcel Dekker, Inc. New York, 173-194.

[128] Dobrota, C. (2004) The Biology of Phosphorus. In: Valsamy-Jones, E. and Gray, R. Eds., Phosphorus in Environmental Technology: Principles and Applications, IWA Publishers, London, 51-77.

[129] Aller, A.J., Bernal, J.L., Nozal, M. and Deban, L. (1990) Effects of Selected Trace Elements on Plant Growth. Journal of the Science of Food and Agriculture, 51, 447-479. http://dx.doi.org/10.1002/jsfa.2740510404

[130] Sumner, M.E. and Farina, M.P. (1986) Phosphorus Interactions with Other Nutrients and Lime in Field Cropping Systems. In: Stewart, B.A., Ed., Advances in Soil Science, Springer, New York, 201-236.

[131] Nziguheba, G., Palm, C.A., Buresh, R.J. and Smithson, P.C. (1998) Soil Phosphorus Fractions and Adsorption as Affected by Organic and Inorganic Sources. Plant and Soil, 198, 159-168. http://dx.doi.org/10.1023/A:1004389704235

[132] Wardle, D.A., Bardgett, R.D., Klironomos, J.N., Setälä, H., Van Der Putten, W.H. and Wall, D.H. (2004) Ecological Linkages between Aboveground and Belowground Biota. Science, 304, 1629-1633. http://dx.doi.org/10.1126/science.1094875

[133] Thung, M. and Rao, I.M. (1999) Integrated Management of Abiotic Stresses. In: Singh, S.P., Ed., Common Bean Improvement in the Twenty-First Century, Springer, Dordrecht, 331-370.

[134] Hardarson, G. (1993) Methods for Enhancing Symbiotic Nitrogen Fixation. In: Bliss, F.A. and Hardarson, G., Eds., Enhancement of Biological Nitrogen Fixation of Common Bean in Latin America, Springer, Dordrecht, 1-17.

[135] Leidi, E.O. and Rodríguez-Navarro, D.N. (2000) Nitrogen and Phosphorus Availability Limit $\mathrm{N}_{2}$ Fixation in Bean. New Phytologist, 147, 337-346. http://dx.doi.org/10.1046/j.1469-8137.2000.00703.x

[136] Zaman, M., Saggar, S., Blennerhassett, J. and Singh, J. (2009) Effect of Urease and Nitrification Inhibitors on N Transformation, Gaseous Emissions of Ammonia and Nitrous Oxide, Pasture Yield and N Uptake in Grazed Pasture System. Soil Biology and Biochemistry, 41, 1270-1280. http://dx.doi.org/10.1016/j.soilbio.2009.03.011

[137] Wu, S., Cao, Z., Li, Z., Cheung, K. and Wong, M. (2005) Effects of Biofertilizer Containing N-Fixer, P and K Solubilizers and AM Fungi on Maize Growth: A Greenhouse Trial. Geoderma, 125, 155-166. http://dx.doi.org/10.1016/j.geoderma.2004.07.003

[138] Asimi, S., Gianinazzi-Pearson, V. and Gianinazzi, S. (1980) Influence of Increasing Soil Phosphorus Levels on Interactions between Vesicular-Arbuscular Mycorrhizae and Rhizobium in Soybeans. Canadian Journal of Botany, 58, 2200-2205. http://dx.doi.org/10.1139/b80-253

[139] Rudresh, D., Shivaprakash, M. and Prasad, R. (2005) Effect of Combined Application of Rhizobium, Phosphate Solubilizing Bacterium and Trichoderma spp. on Growth, Nutrient Uptake and Yield of Chickpea (Ciceraritenium L.). Ap- 
plied Soil Ecology, 28, 139-146. http://dx.doi.org/10.1016/j.apsoil.2004.07.005

[140] Lawton, K. and Cook, R. (1954) Potassium in Plant Nutrition. Advances in Agronomy, 6, 253-303. http://dx.doi.org/10.1016/S0065-2113(08)60387-9

[141] Clarkson, D.T. and Hanson, J.B. (1980) The Mineral Nutrition of Higher Plants. Annual Review of Plant Physiology, 31, 239-298. http://dx.doi.org/10.1146/annurev.pp.31.060180.001323

[142] Olsen, R.A. and Kurtz, L.T. (1982) Crop Nitrogen Requirements, Utilization and Fertilization. In: Stevenson, F.J., Nitrogen in Agricultural Soils, American Society of Agronomy, Madison, 567-604.

[143] Wilson, J.B. (1988) A Review of Evidence on the Control of Shoot: Root Ratio, in Relation to Models. Annals of Botany, 61, 433-449.

[144] Pettigrew, W.T. (2008) Potassium Influences on Yield and Quality Production for Maize, Wheat, Soybean and Cotton. Physiologia Plantarum, 133, 670-681. http://dx.doi.org/10.1111/j.1399-3054.2008.01073.x

[145] Ayub, M., Nadeem, M., Naeem, M., Tahir, M., Tariq, M. and Ahmad, W. (2012) Effect of Different Levels of P and K on Growth, Forage Yield and Quality of Cluster Bean (Cyamopsis tetragonolobus L.). Journal of Animal and Plant Sciences, 22, 479-483.

[146] Paudyal, S., Aryal, R.R., Chauhan, S. and Maheshwari, D. (2007) Effect of Heavy Metals on Growth of Rhizobium Strains and Symbiotic Efficiency of Two Species of Tropical Legumes. Scientific World, 5, 27-32.

[147] Ike-Izundu, N.E. (2008) Interaction between Arbuscular Mycorrhizal Fungi and Soil Microbial Populations in the Rhizosphere. Thesis, Rhodes University, Rhodes.

[148] Okon, Y. and Hardy, R. (1983) Developments in Basic and Applied Biological Nitrogen Fixation. Plant Physiology-A Treatise, 8, 5-54.

[149] Seresinhe, T. and Pathirana, K. (2001) Effects of Phosphorous and Potassium on the Growth and Nodulation of Centrosema spp. Journal of Agriculture in the Tropics and Subtropics, 102, 45-52.

[150] Seresinhe, T. and Pathirana, K. (2002) Cover Crop, Centrosema spp., N-Fixation, Phosphorous, Potassium. Journal of Agriculture in the Tropics and Subtropics, 103, 73-79.

[151] Arora, P., Yadav, R., Dilbaghi, N. and Chaudhury, A. (2012) Biological Nitrogen Fixation: Host-Rhizobium Interaction. Frontiers on Recent Developments in Plant Science, 1, 39-59.

[152] Andrade, D., Murphy, P. and Giller, K. (2002) Effects of Liming and Legume/Cereal Cropping on Populations of Indigenous Rhizobia in an Acid Brazilian Oxisol. Soil Biology and Biochemistry, 34, 477-485. http://dx.doi.org/10.1016/S0038-0717(01)00206-1

[153] Salvagiotti, F., Cassman, K.G., Specht, J.E., Walters, D.T., Weiss, A. and Dobermann, A. (2008) Nitrogen Uptake, Fixation and Response to Fertilizer N in Soybeans: A Review. Field Crops Research, 108, 1-13. http://dx.doi.org/10.1016/j.fcr.2008.03.001

[154] Gupta, R., Kalia, A. and Kapoor, S. (2007) Bioinoculants: A Step towards Sustainable Agriculture. New India Publishing, New Delhi.

[155] Dash, S. and Gupta, N. (2011) Microbial Bioinoculants and Their Role in Plant Growth and Development. International Journal of Biotechnology and Molecular Biology Research, 2, 232-251.

[156] Niehaus, K., Lagares, A. and Pühler, A. (1998) A Sinorhizobium meliloti Lipopolysaccharide Mutant Induces Effective Nodules on the Host Plant Medicago sativa (Alfalfa) but Fails to Establish a Symbiosis with Medicago truncatula. Molecular Plant-Microbe Interactions, 11, 906-914. http://dx.doi.org/10.1094/MPMI.1998.11.9.906

[157] Hirsch, A.M., Lum, M.R. and Downie, J.A. (2001) What Makes the Rhizobia-Legume Symbiosis So Special? Plant Physiology, 127, 1484-1492. http://dx.doi.org/10.1104/pp.010866

[158] Beringer, J.E. and Johnston, A.W. (1984) The Significance of Symbiotic Nitrogen Fixation in Plant Production. Critical Reviews in Plant Sciences, 1, 269-286. http://dx.doi.org/10.1080/07352688409382181

[159] Maier, R.J. and Triplett, E.W. (1996) Toward More Productive, Efficient and Competitive Nitrogen-Fixing Symbiotic Bacteria. Critical Reviews in Plant Sciences, 15, 191-234. http://dx.doi.org/10.1080/07352689609701941

[160] Cooper, J.E. (2004) Multiple Responses of Rhizobia to Flavonoids during Legume Root Infection. Advances in Botanical Research, 41, 1-62. http://dx.doi.org/10.1016/S0065-2296(04)41001-5

[161] Sprent, J.I. and Raven, J.A. (1985) Evolution of Nitrogen-Fixing Symbioses. Proceedings of the Royal Society of Edinburgh. Section B. Biological Sciences, 85, 215-237. http://dx.doi.org/10.1017/S0269727000004036

[162] Vance, C.P. (1998) Legume Symbiotic Nitrogen Fixation: Agronomic Aspects. In: Spaink, H.P., Kondorosi, A. and Hooykaas, P.J.J., Eds., The Rhizobiaceae, Springer, Dordrecht, 509-530.

[163] Geers, R., Van der Veken, L., Swennen, R. and Michiels, J. (2010) Potential of Multipurpose Intercrops for the Management of Pathogenic Nematodes and Beneficial Arbuscular Mycorrhizal Fungi and Root Nodulating Rhizobacteria 
in Banana-Based Cropping Systems. Ph.D. Studies, KU Leuven, Leuven.

[164] Parthipan, S. and Kulasooriya, S. (1989) Effect of Nitrogen- and Potassium-Based Fertilizers on Nitrogen Fixation in the Winged Bean, Psophocarpus tetragonolobus. MIRCEN Journal of Applied Microbiology and Biotechnology, 5, 335-341. http://dx.doi.org/10.1007/BF01741764

[165] Premaratne, K. and Oertli, J. (1994) The Influence of Potassium Supply on Nodulation, Nitrogenase Activity and Nitrogen Accumulation of Soybean (Glycine max L. Merrill) Grown in Nutrient Solution. Fertilizer Research, 38, 95-99. http://dx.doi.org/10.1007/BF00748769

[166] Weisany, W., Raei, Y. and Allahverdipoor, K.H. (2013) Role of Some of Mineral Nutrients in Biological Nitrogen Fixation. Bulletin of Environment, Pharmacology and Life Sciences, 2, 77-84.

[167] Subba Rao, N.S. and Tilak, K.V.B.R. (1977) Rhizobial Cultures-Their Role in Pulse Production. In: Subba Rao, N.S., Ed., Souvenier Bulletin, Directorate of Pulse Development, Oxford and IBH, New Delhi, 1-19.

[168] Koide, R.T. (1991) Nutrient Supply, Nutrient Demand and Plant Response to Mycorrhizal Infection. New Phytologist, 117, 365-386. http://dx.doi.org/10.1111/j.1469-8137.1991.tb00001.x

[169] Stewart, A., Chapman, W., Jenkins, G., Graham, I., Martin, T. and Crozier, A. (2001) The Effect of Nitrogen and Phosphorus Deficiency on Flavonol Accumulation in Plant Tissues. Plant, Cell \& Environment, 24, 1189-1197. http://dx.doi.org/10.1046/j.1365-3040.2001.00768.x

[170] Shin, R., Berg, R.H. and Schachtman, D.P. (2005) Reactive Oxygen Species and Root Hairs in Arabidopsis Root Response to Nitrogen, Phosphorus and Potassium Deficiency. Plant and Cell Physiology, 46, 1350-1357. http://dx.doi.org/10.1093/pcp/pci145

[171] Boddey, R.M., De Moraes Sá, J.C., Alves, B.J. and Urquiaga, S. (1997) The Contribution of Biological Nitrogen Fixation for Sustainable Agricultural Systems in the Tropics. Soil Biology and Biochemistry, 29, 787-799. http://dx.doi.org/10.1016/S0038-0717(96)00221-0

[172] Christophe, S., Jean-Christophe, A., Annabelle, L., Alain, O., Marion, P. and Anne-Sophie, V. (2011) Plant N Fluxes and Modulation by Nitrogen, Heat and Water Stresses: A Review Based on Comparison of Legumes and Non Legume Plants. In: Shanker, A. and Venkateswarlu, B., Eds., Abiotic Stress in Plants-Mechanisms and Adaptations, InTech.

[173] Bergersen, F. (1971) Biochemistry of Symbiotic Nitrogen Fixation in Legumes. Annual Review of Plant Physiology, 22, 121-140. http://dx.doi.org/10.1146/annurev.pp.22.060171.001005

[174] Jakobsen, I. (1985) The Role of Phosphorus in Nitrogen Fixation by Young Pea Plants (Pisum sativum). Physiologia Plantarum, 64, 190-196. http://dx.doi.org/10.1111/j.1399-3054.1985.tb02334.x

[175] Israel, D.W. (1993) Symbiotic Dinitrogen Fixation and Host-Plant Growth during Development of and Recovery from Phosphorus Deficiency. Physiologia Plantarum, 88, 294-300. http://dx.doi.org/10.1111/j.1399-3054.1993.tb05502.x

[176] Hart, S.R. and Dunn, T. (1993) Experimental Cpx/Melt Partitioning of 24 Trace Elements. Contributions to Mineralogy and Petrology, 113, 1-8. http://dx.doi.org/10.1007/BF00320827

[177] Stamford, N., Lima, R., Santos, C. and Dias, S. (2006) Rock Biofertilizers with Acidithiobacillus on Sugarcane Yield and Nutrient Uptake in a Brazilian Soil. Geomicrobiology Journal, 23, 261-265. http://dx.doi.org/10.1080/01490450600760658

[178] Singleton, P., AbdelMagid, H. and Tavares, J. (1985) Effect of Phosphorus on the Effectiveness of Strains of Rhizobium japonicum. Soil Science Society of America Journal, 49, 613-616. http://dx.doi.org/10.2136/sssaj1985.03615995004900030016x

[179] Schiffmann, J. (1982) Biological and Agronomic Aspects of Legume Inoculation in Israel. Israel Journal of Botany, 31, 265-281.

[180] Ribet, J. and Drevon, J.-J. (1995) Phosphorus Deficiency Increases the Acetylene-Induced Decline in Nitrogenase Activity in Soybean (Glycine max (L.) Merr.). Journal of Experimental Botany, 46, 1479-1486. http://dx.doi.org/10.1093/jxb/46.10.1479

[181] Drevon, J.-J. and Hartwig, U.A. (1997) Phosphorus Deficiency Increases the Argon-Induced Decline of Nodule Nitrogenase Activity in Soybean and Alfalfa. Planta, 201, 463-469. http://dx.doi.org/10.1007/s004250050090

[182] Parsons, R., Stanforth, A., Raven, J. and Sprent, J. (1993) Nodule Growth and Activity May Be Regulated by a Feedback Mechanism Involving Phloem Nitrogen. Plant, Cell \& Environment, 16, 125-136. http://dx.doi.org/10.1111/j.1365-3040.1993.tb00854.x

[183] Rufty, T.W., Israel, D.W., Volk, R.J., Qiu, J. and Sa, T. (1993) Phosphate Regulation of Nitrate Assimilation in Soybean. Journal of Experimental Botany, 44, 879-891. http://dx.doi.org/10.1093/jxb/44.5.879

[184] Sa, T. and Israel, D. (1995) Nitrogen Assimilation in Nitrogen-Fixing Soybean Plants during Phosphorus Deficiency. Crop Science, 35, 814-820. http://dx.doi.org/10.2135/cropsci1995.0011183X003500030030x

[185] Ngatunga, E., Lal, R. and Uriyo, A. (1984) Effects of Surface Management on Runoff and Soil Erosion from Some 
Plots at Mlingano, Tanzania. Geoderma, 33, 1-12. http://dx.doi.org/10.1016/0016-7061(84)90086-7

[186] Muchena, F. and Kiome, R. (1995) The Role of Soil Science in Agricultural Development in East Africa. Geoderma, 67, 141-157. http://dx.doi.org/10.1016/0016-7061(95)00015-G

[187] Buttery, B., Park, S. and Findlay, W. (1987) Growth and Yield of White Bean (Phaseolus vulgaris L.) in Response to Nitrogen, Phosphorus and Potassium Fertilizer and to Inoculation with Rhizobium. Canadian Journal of Plant Science, 67, 425-432. http://dx.doi.org/10.4141/cjps87-061

[188] Abdelhamid, M.T., Kamel, H. and Dawood, M.G. (2011) Response of Non-Nodulating, Nodulating and Super-Nodulating Soybean Genotypes to Potassium Fertilizer under Water Stress. Journal of Plant Nutrition, 34, 16751689. http://dx.doi.org/10.1080/01904167.2011.592563

[189] Abbasi, M.K., Tahir, M.M., Azam, W., Abbas, Z. and Rahim, N. (2012) Soybean Yield and Chemical Composition in Response to Phosphorus-Potassium Nutrition in Kashmir. Agronomy Journal, 104, 1476-1484. http://dx.doi.org/10.2134/agronj2011.0379

[190] Mengel, K., Kosegarten, H., Kirkby, E.A. and Appel, T. (2001) Principles of Plant Nutrition. Springer, Dordrecht. http://dx.doi.org/10.1007/978-94-010-1009-2

[191] Sangakkara, U., Frehner, M. and Nösberger, J. (2000) Effect of Soil Moisture and Potassium Fertilizer on Shoot Water Potential, Photosynthesis and Partitioning of Carbon in Mungbean and Cowpea. Journal of Agronomy and Crop Science, 185, 201-207. http://dx.doi.org/10.1046/j.1439-037x.2000.00422.x

[192] Imas, P. and Bansal, S. (1999) Potassium and Integrated Nutrient Management in Potato. Proceedings of the Global Conference on Potato, New Delhi, 6-11 December 1999, 6-11.

[193] Odee, D., Sutherland, J., Makatiani, E., McInroy, S. and Sprent, J. (1997) Phenotypic Characteristics and Composition of Rhizobia Associated with Woody Legumes Growing in Diverse Kenyan Conditions. Plant and Soil, 188, 65-75. http://dx.doi.org/10.1023/A:1004204413140

[194] Zahran, H.H. (1999) Rhizobium-Legume Symbiosis and Nitrogen Fixation under Severe Conditions and in an Arid Climate. Microbiology and Molecular Biology Reviews, 63, 968-989.

[195] O’Hara, G. (2001) Nutritional Constraints on Root Nodule Bacteria Affecting Symbiotic Nitrogen Fixation: A Review. Animal Production Science, 41, 417-433. http://dx.doi.org/10.1071/EA00087

[196] Makoi, J.H. and Ndakidemi, P.A. (2008) Selected Soil Enzymes: Examples of Their Potential Roles in the Ecosystem. African Journal of Biotechnology, 7, 181-191.

[197] Torres Gutiérrez, R. (2008) Phytostimulatory Effect of Rhizobium and Plant Growth Promoting Rhizobacteria in Common Bean (Phaseolus vulgaris L.) Interaction.

[198] Sumi, L.S. (1997) Seasonal Availability and Mineralization of Nitrogen in Cotton and Soybean Cropping Systems in Mississippi. Master's Thesis, University of Toronto, Toronto.

[199] Birkhold, K.T. and Darnell, R.L. (1991) Contribution of Carbon and Nitrogen Reserves to Vegetative and Reproductive Growth of Rabbiteye Blueberry. HortScience, 26, 682-682.

[200] Porter, J.R. and Lawlor, D.W. (1991) Plant Growth: Interactions with Nutrition and Environment. Cambridge University Press, Cambridge.

[201] Sanginga, N., Dashiell, K., Diels, J., Vanlauwe, B., Lyasse, O., Carsky, R., et al. (2003) Sustainable Resource Management Coupled to Resilient Germplasm to Provide New Intensive Cereal-Grain-Legume-Livestock Systems in the Dry Savanna. Agriculture, Ecosystems \& Environment, 100, 305-314. http://dx.doi.org/10.1016/S0167-8809(03)00188-9

[202] Marenya, P.P. and Barrett, C.B. (2009) Soil Quality and Fertilizer Use Rates among Smallholder Farmers in Western Kenya. Agricultural Economics, 40, 561-572. http://dx.doi.org/10.1111/j.1574-0862.2009.00398.x

[203] Martins, O., Gideon, O. and Beatrice, S. (2009) Factors Responsible for Differences in Uptake of Integrated Soil Fertility Management Practices amongst Smallholders in Western Kenya. African Journal of Agricultural Research, 4, 1303-1311.

[204] Phoenix, G.K., Hicks, W.K., Cinderby, S., Kuylenstierna, J.C., Stock, W.D., Dentener, F.J., et al. (2006) Atmospheric Nitrogen Deposition in World Biodiversity Hotspots: The Need for a Greater Global Perspective in Assessing N Deposition Impacts. Global Change Biology, 12, 470-476. http://dx.doi.org/10.1111/j.1365-2486.2006.01104.X

[205] Onduru, D., De Jager, A., Muchena, F., Gachini, G. and Gachimbi, L. (2008) Exploring Potentials of Rhizobium Inoculation in Enhancing Soil Fertility and Agro-Economic Performance of Cowpeas in Sub-Saharan Africa: A Case Study in Semi-Arid Mbeere, Eastern Kenya. American-Eurasian Journal of Sustainable Agriculture, 2, 187-195.

[206] Panwar, J. and Laxmi, V. (2005) Biological Nitrogen Fixation in Pulses and Cereals. Developments in Physiology, Biochemistry and Molecular Biology of Plants, 1, 125. 
[207] Williams, R. (1948) The Effects of Phosphorus Supply on the Rates of Intake of Phosphorus and Nitrogen and upon Certain Aspects of Phosphorus Metabolism in Gramineous Plants. Australian Journal of Biological Sciences, 1, 333361.

[208] Pramanick, B., Brahmachari, K. and Ghosh, A. (2013) Effect of Seaweed Saps on Growth and Yield Improvement of Green Gram. African Journal of Agricultural Research, 8, 1180-1186.

[209] Andrew, C. and Robins, M. (1969) The Effect of Phosphorus on the Growth and Chemical Composition of Some Tropical Pasture Legumes. I. Growth and Critical Percentages of Phosphorus. Crop and Pasture Science, 20, 665-674. http://dx.doi.org/10.1071/AR9690665

[210] Singleton, P. and Tavares, J. (1986) Inoculation Response of Legumes in Relation to the Number and Effectiveness of Indigenous Rhizobium Populations. Applied and Environmental Microbiology, 51, 1013-1018.

[211] Wani, S., Rupela, O. and Lee, K. (1995) Sustainable Agriculture in the Semi-Arid Tropics through Biological Nitrogen Fixation in Grain Legumes. In: Ladha, J.K. and Peoples, M.B., Eds., Management of Biological Nitrogen Fixation for the Development of More Productive and Sustainable Agricultural Systems, Springer, Dordrecht, 29-49.

[212] Turuko, M. and Mohammed, A. (2014) Effect of Different Phosphorus Fertilizer Rates on Growth, Dry Matter Yield and Yield Components of Common Bean (Phaseolus vulgaris L.). World Journal of Agricultural Research, 2, 88-92. http://dx.doi.org/10.12691/wjar-2-3-1

[213] Borges, R. and Mallarino, A.P. (2000) Grain Yield, Early Growth and Nutrient Uptake of No-Till Soybean as Affected by Phosphorus and Potassium Placement. Agronomy Journal, 92, 380-388. http://dx.doi.org/10.2134/agronj2000.922380x

[214] Dakora, F. and Keya, S. (1997) Contribution of Legume Nitrogen Fixation to Sustainable Agriculture in Sub-Saharan Africa. Soil Biology and Biochemistry, 29, 809-817. http://dx.doi.org/10.1016/S0038-0717(96)00225-8

[215] Palm, C.A., Gachengo, C.N., Delve, R.J., Cadisch, G. and Giller, K.E. (2001) Organic Inputs for Soil Fertility Management in Tropical Agroecosystems: Application of an Organic Resource Database. Agriculture, Ecosystems \& Environment, 83, 27-42. http://dx.doi.org/10.1016/S0167-8809(00)00267-X

[216] Tsai, S.M., Da Silva, P.M., Cabezas, W.L. and Bonetti, R. (1993) Variability in Nitrogen Fixation of Common Bean (Phaseolus vulgaris L.) Intercropped with Maize. Plant and Soil, 152, 93-101.

[217] Nandwa, S.M. and Bekunda, M. (1998) Research on Nutrient Flows and Balances in East and Southern Africa: State-of-the-Art. Agriculture, Ecosystems \& Environment, 71, 5-18. http://dx.doi.org/10.1016/S0167-8809(98)00128-5 
Scientific Research Publishing (SCIRP) is one of the largest Open Access journal publishers. It is currently publishing more than 200 open access, online, peer-reviewed journals covering a wide range of academic disciplines. SCIRP serves the worldwide academic communities and contributes to the progress and application of science with its publication.

Other selected journals from SCIRP are listed as below. Submit your manuscript to us via either submit@scirp.org or Online Submission Portal.
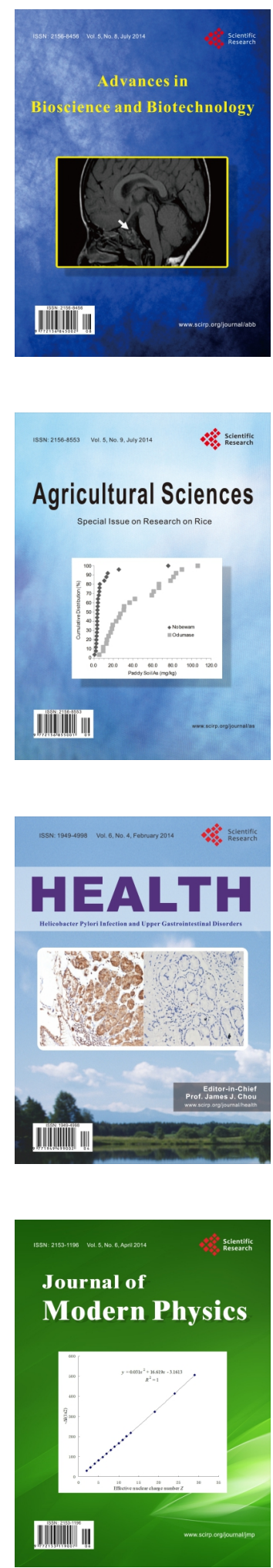
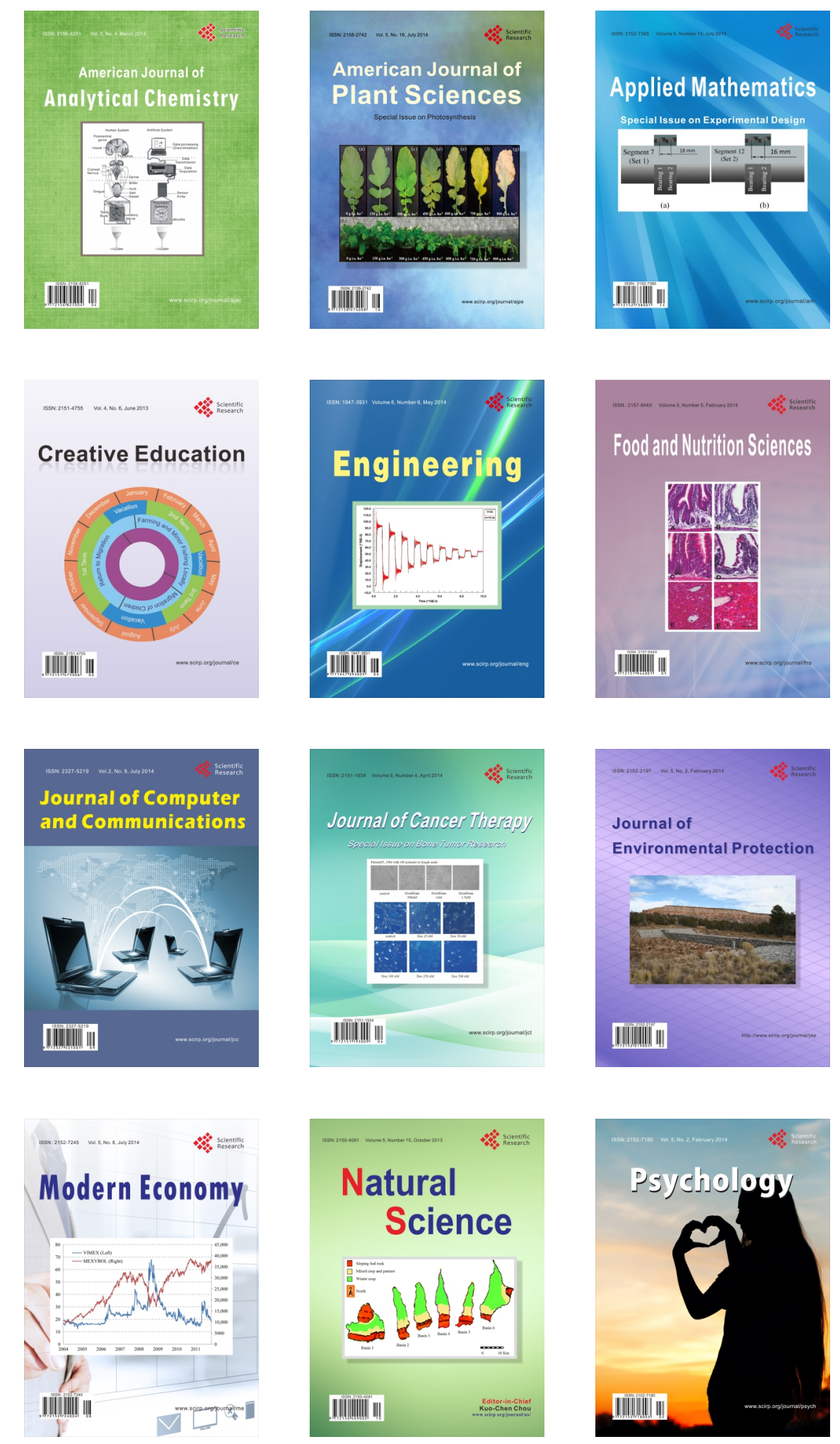